\title{
Fungicides: An Overlooked Pesticide Class?
}

Jochen P. Zubrod, ${ }^{* \dagger, \ddagger(0)}$ Mirco Bundschuh, ${ }^{\dagger, \S}$ Gertie Arts, ${ }^{\|}$Carsten A. Brühl, ${ }^{\dagger}$ Gwenaël Imfeld, ${ }^{\perp}$ Anja Knäbel, ${ }^{\dagger}$ Sylvain Payraudeau, ${ }^{\perp}{ }^{\odot}$ Jes J. Rasmussen, ${ }^{\#}$ Jason Rohr, ${ }^{\nabla, \Delta}{ }^{\text {Andreas Scharmüller, }}{ }^{\dagger}$ Kelly Smalling, Sebastian Stehle, ${ }^{\dagger, \dagger}$ Ralf Schulz, ${ }^{\dagger, \ddagger}$ and Ralf B. Schäfer ${ }^{\dagger \oplus}$

${ }^{\dagger}$ Institute for Environmental Sciences, University of Koblenz-Landau, Fortstraße 7, D-76829 Landau, Germany

${ }^{\ddagger}$ Eußerthal Ecosystem Research Station, University of Koblenz-Landau, Birkenthalstraße 13, D-76857 Eußerthal, Germany

${ }^{\S}$ Department of Aquatic Sciences and Assessment, Swedish University of Agricultural Sciences, Lennart Hjelms väg 9, SWE-75007 Uppsala, Sweden

"Wageningen Environmental Research, Wageningen University and Research, Wageningen, The Netherlands

${ }^{\perp}$ Laboratoire d'Hydrologie et de Géochimie de Strasbourg (LHyGeS), Université de Strasbourg/ENGEES, CNRS, 1 rue Blessig, 67084 Strasbourg Cedex, France

\#Aarhus University, Dept. of Bioscience, Vejlsoevej 25, 8600 Silkeborg, Denmark

${ }^{\nabla}$ University of South Florida, Department of Integrative Biology, Tampa, Florida, United States

${ }^{\Delta}$ Department of Biological Sciences, Environmental Change Initiative, and Eck Institute for Global Health, University of Notre Dame, Notre Dame, Indiana, United States

OU.S. Geological Survey, New Jersey Water Science Center, Lawrenceville, New Jersey, United States

Supporting Information

ABSTRACT: Fungicides are indispensable to global food security and their use is forecasted to intensify. Fungicides can reach aquatic ecosystems and occur in surface water bodies in agricultural catchments throughout the entire growing season due to their frequent, prophylactic application. However, in comparison to herbicides and insecticides, the exposure to and effects of fungicides have received less attention. We provide an overview of the risk of fungicides to aquatic ecosystems covering fungicide exposure (i.e., environmental fate, exposure modeling, and mitigation measures) as well as direct and indirect effects of fungicides on microorganisms, macrophytes, invertebrates, and vertebrates. We show that fungicides occur widely in aquatic systems, that the accuracy of predicted

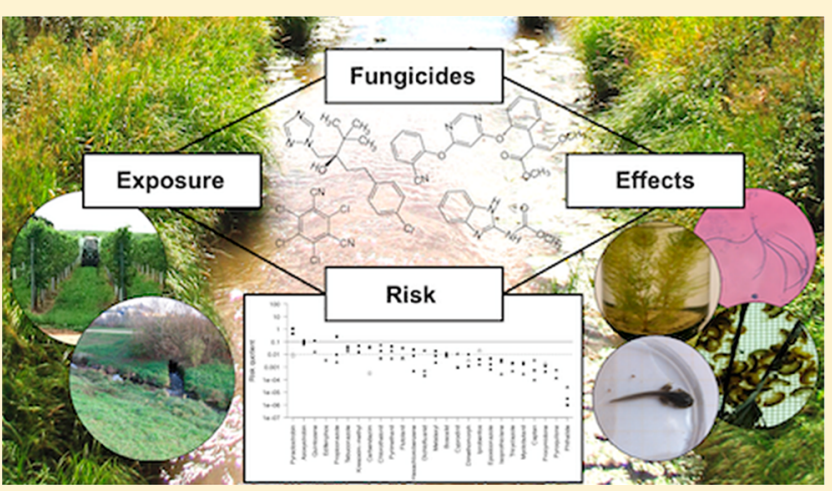
environmental concentrations is debatable, and that fungicide exposure can be effectively mitigated. We additionally demonstrate that fungicides can be highly toxic to a broad range of organisms and can pose a risk to aquatic biota. Finally, we outline central research gaps that currently challenge our ability to predict fungicide exposure and effects, promising research avenues, and shortcomings of the current environmental risk assessment for fungicides.

\section{INTRODUCTION}

As fungal diseases are a major threat to crop production, ${ }^{1}$ the application of fungicides to control fungal infestations is often considered indispensable to secure global food supply. ${ }^{2}$ In the European Union (EU), fungicide sales (based on mass) account for more than $40 \%$ of the total pesticide sales with synthetic, organic fungicides accounting for approximately $60 \%$ of all fungicides. ${ }^{3}$ In wine-growing regions, fungicides can account for more than $90 \%$ of all pesticide applications. ${ }^{4}$ Moreover, fungicide use is regionally predicted to increase because of changes to climatic conditions, development of fungicide resistance, and invasive fungal species. ${ }^{1,5,6}$ Following their use, fungicides can enter aquatic ecosystems via point (e.g., discharge from wastewater treatment plants following domestic and agricultural use ${ }^{7}$ ) and nonpoint (e.g., drift, drainage, surface runoff primarily from agricultural use ${ }^{8}$ ) sources. In aquatic systems, fungicides can be toxic to a wide range of nontarget organisms as they act on basic biological processes that are not specific to fungi (e.g., energy production). ${ }^{9,10}$ Despite intensive use of fungicides and the associated potential ecotoxicological risks in nontarget aquatic

Received: August 7, 2018

Revised: December 14, 2018

Accepted: March 5, 2019

Published: March 5, 2019 


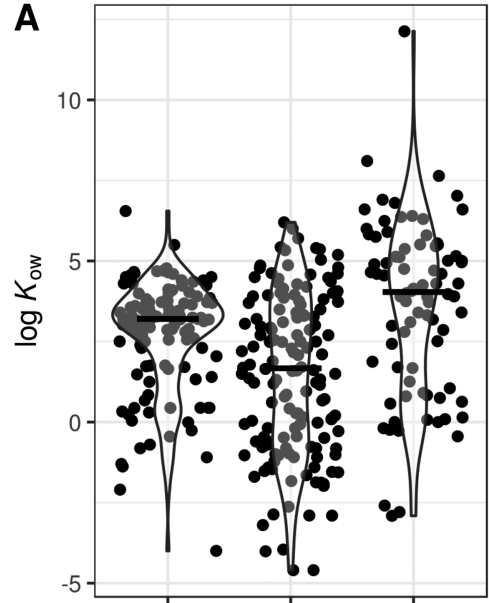

Fungicides Herbicides Insecticides

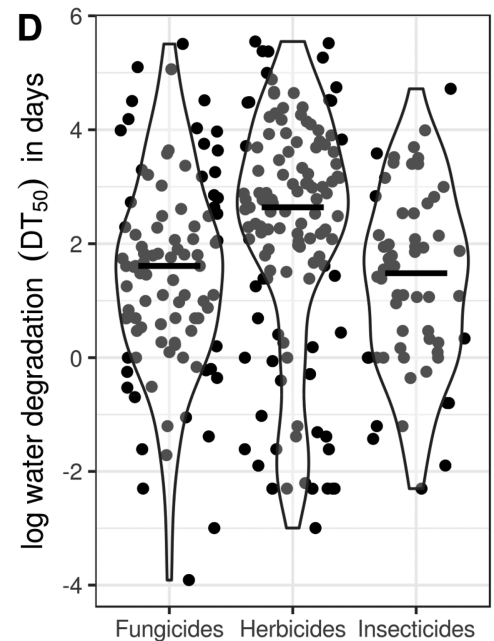

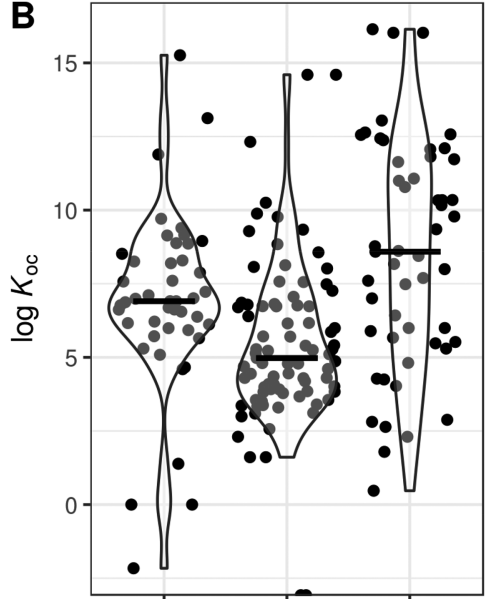

Fungicides Herbicides Insecticides

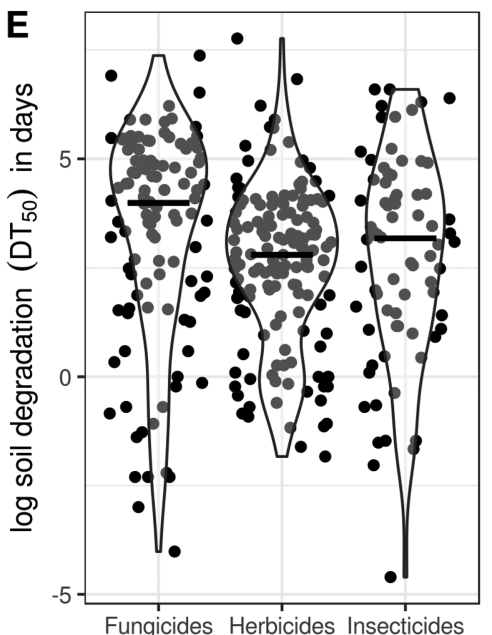

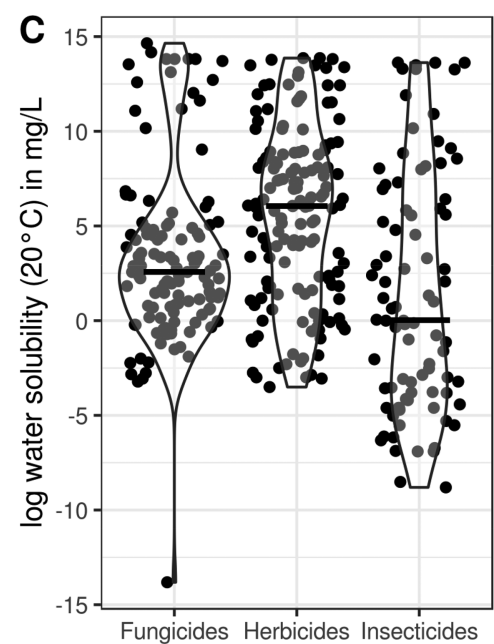

Fungicides Herbicides Insecticides

Figure 1. Violin plots of physicochemical properties related to pesticide mobility and dissipation in aquatic systems for fungicides, herbicides, and insecticides currently registered for use in the EU (fungicides: $n=120 / 45 / 124 / 95 / 106$, herbicides: $n=150 / 83 / 148 / 123 / 145$, insecticides: $n=$ 82/51/86/60/74, for A, B, C, D, and E, respectively; extracted from the Pesticide Properties DataBase ${ }^{40}$ ). Black bars within violins represent medians. To facilitate readability, data points are randomly scattered along a hypothetical $x$-axis and are greyed out within the violins.

systems, the environmental fate and effects of fungicides have received far less attention compared to insecticides and herbicides. For instance, only $13 \%$ of studies on pesticide effects between 1991 and 2013 focused on fungicides, compared to $62 \%$ and $24 \%$ for insecticides and herbicides, respectively. ${ }^{11}$

Therefore, we provide an overview of the risk of fungicides to aquatic ecosystems. Our review (details on the literature search can be found in the Supporting Information (SI)) focused on synthetic, organic fungicides given that the fate and effects of inorganic fungicides, such as copper, have been reviewed previously. ${ }^{12,13}$ The first part of our review focuses on fungicide exposure including environmental fate, exposure modeling, and mitigation measures. Subsequently, we review direct and indirect (i.e., mediated through another species/ organism group that has been directly affected) effects of fungicides on microorganisms, macrophytes, invertebrates, and vertebrates. In the third part, we evaluate the risk based on the fungicide exposure and toxicity in aquatic environments. Finally, we distill research gaps and avenues for future exploration and provide recommendations for amendments of current environmental risk assessment (ERA) procedures for fungicides.

\section{EXPOSURE}

Use. In agricultural landscapes, fungicides are used predominantly on fruits and vegetables and contribute to more than $35 \%$ of the pesticide market share worldwide. ${ }^{14}$ Geographically, Europe is considered the dominant market for fungicides with major applications on grains and cereals (e.g., wheat), fruits (with particularly intensive use in viticulture), and vegetables. ${ }^{14}$ In the United States (U.S.), which represents $80 \%$ of the total fungicide use in North America, ${ }^{14}$ fungicides account for less than $10 \%$ (including inorganic fungicides) of the total mass of pesticides applied. ${ }^{15}$ Dithiocarbamates, chloronitriles, demethylation inhibitors (DMIs), and strobilurins constitute major fungicide groups accounting for approximately $65,12,7$, and $6 \%$ of the total synthetic fungicide mass used in the U.S. (estimated based on U.S. Geological Survey's (USGS's) preliminary data for $2016^{15}$ ). Moreover, dithiocarbamates (aggregated with carbamates) and DMI fungicides account for approximately 29 and $24 \%$ of the mass of synthetic fungicides sold in the EU, whereas specific data on chloronitriles and strobilurins are lacking (subsumed under "other fungicides" accounting for more than 40\%; estimates for 11 member states reporting sales ${ }^{3}$ ). 

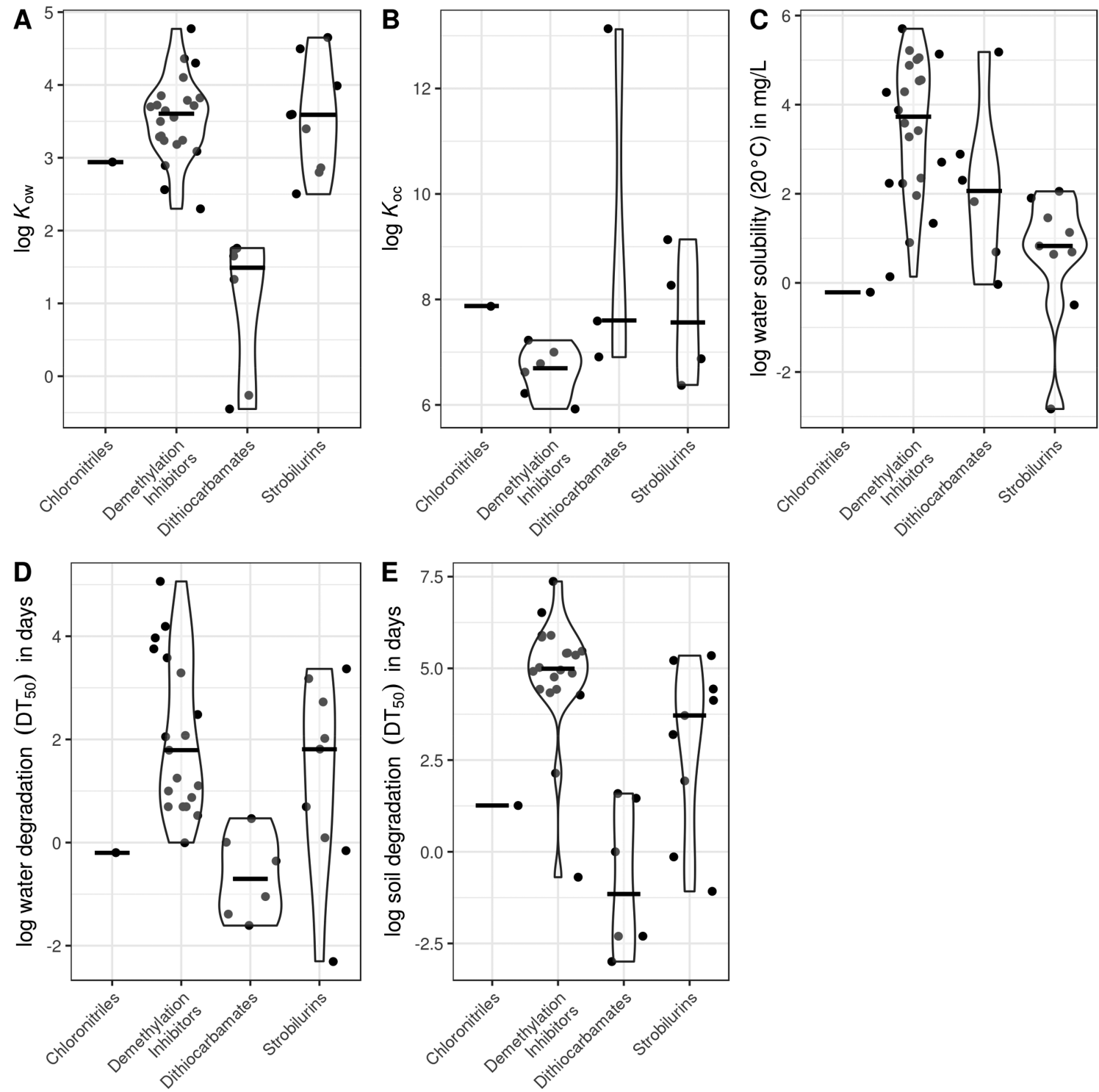

Figure 2. Violin plots of physicochemical properties related to pesticide mobility and dissipation in aquatic systems for major fungicide groups (only substances currently registered for use in the EU are shown; chloronitriles [i.e., chlorothalonil]: $n=1 / 1 / 1 / 1 / 1$, demethylation inhibitors: $n=$ 22/6/22/19/20, dithiocarbamates: $n=6 / 3 / 6 / 6 / 6$, strobilurins: $n=9 / 4 / 9 / 9 / 9$, for A, B, C, D, and E, respectively; extracted from the Pesticide Properties DataBase $\left.{ }^{40}\right)$. See caption of Figure 1 for more details.

Fungicides are applied either to seeds or directly on crops. Many of the seed-treated fungicides possess systemic action, that is, they can be taken up into plant tissues where they provide protection against pests and pathogens similar to their insecticidal counterparts. ${ }^{16,17}$ Seed-applied fungicides are effective against soil-borne pathogens, but have the potential to persist at low concentrations for up to several months in the plant or the rhizosphere. ${ }^{18-20}$ Regarding direct application on crops, the common use of fungicides in three-dimensional crops, such as trees and vine branches, can drastically increase the drift distances with higher nozzle height increasing the risk of fungicide transport to adjacent aquatic systems. ${ }^{21}$ This risk is heightened since fungicides, unlike most other pesticides, are typically applied prophylactically and often as frequently as 10 times per season to target crops, such as grapes. ${ }^{22}$

Despite the intensive fungicide use, fungal pathogens are responsible for $7-24 \%$ of losses in yields to commodity crops, ${ }^{1,23}$ which can partly be attributed to the development of resistance to commonly used fungicides. Depending on the pathogen genome and the mode of fungicidal action, fungal pathogens can develop resistance within a few years of exposure. ${ }^{24,25}$ This requires a constant search for new fungicides and novel treatment strategies. Effective measures to prevent resistance include decreasing both amount and application frequency, ${ }^{26}$ or combining the application of several fungicides with different modes of action. ${ }^{27,28}$

In urban areas, fungicides released from paints and coatings on walls, flat roofs, and basement seals can contribute considerably to fungicide inputs into aquatic ecosystems. ${ }^{29-32}$ Because of the need for long-term protection, urban fungicide application to buildings can occur year-round, which can lead to fungicide mobilization primarily during precipitation events. $^{32,33}$ Moreover, fungicides are applied to public and private spaces (e.g., golf courses, lawns, gardens), ${ }^{34}$ and were detected in both treated and untreated wastewater resulting from their use as human pharmaceuticals, as well as in wood and coating preservatives. ${ }^{7,35}$ Consequently, fungicides used intensively in both agricultural and urban landscapes are 


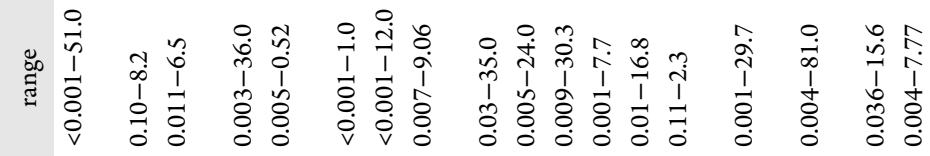

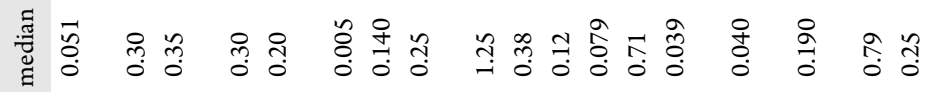

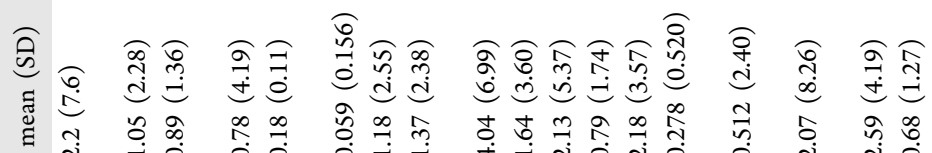

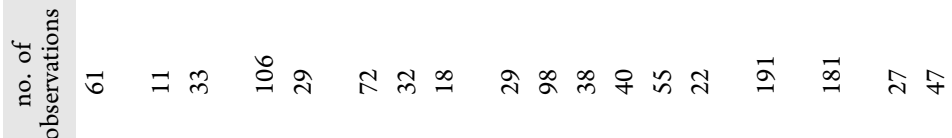
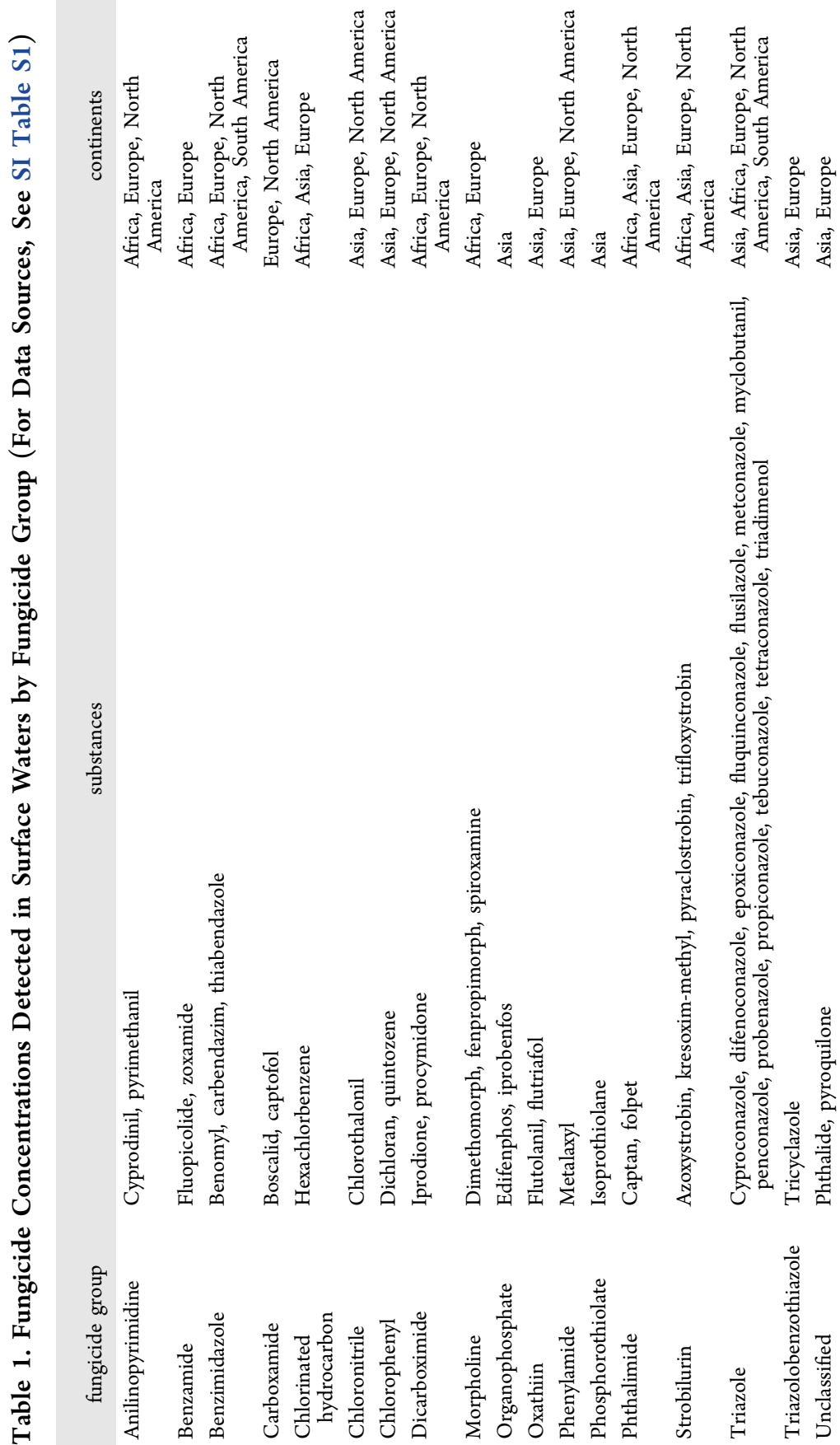
released into the environment throughout the year potentially posing a risk to aquatic organisms.

Physico-Chemical Properties. In general, fungicides are moderately lipophilic (median log octanol-water partition coefficient $\left(K_{\mathrm{ow}}\right): 3.2$; Figure $\left.1 \mathrm{~A}\right)$, a feature well-reflected by all major fungicide groups except for dithiocarbamates (median $\log K_{\text {ow }}: 1.5$; Figure $2 \mathrm{~A}$ ). Moreover, fungicides in general have moderate to high adsorption potential to organic carbon (median log organic carbon-water partition coefficient $\left(K_{\mathrm{oc}}\right)$ : 6.9; range of median $\log K_{\mathrm{oc}}$ for the four major fungicide groups: 6.7-7.9; Figures $1 \mathrm{~B}$ and $2 \mathrm{~B}$ ). Consequently, fungicides may adsorb to sediments and organic surfaces in aquatic systems as documented in several field studies. ${ }^{36-39}$ Similar to highly lipophilic pesticides, such as pyrethroid and organophosphate insecticides $\left(\log K_{\mathrm{ow}} 5-7\right)$, the amount of sorbed fungicides is typically positively correlated with the content of organic carbon in particle complexes. ${ }^{38}$ In spite of their lipophilic properties, fungicides still exhibit moderate to high mobility in the soil/pore water matrix, ${ }^{22}$ as emphasized by their frequent detection in water, while their water solubility is highly group-specific (range of medians for log water solubility: -0.2 to 3.7 ; Figure 2C). Moreover, fungicides are moderately to highly persistent in water (median 50\% dissipation time $\left(\mathrm{DT}_{50}\right): 5$ days; also referred to as half-life) as well as in soils (median $\mathrm{DT}_{50}$ : 54 days), with half-lives similar to herbicides and insecticides (Figure 1D,E). ${ }^{40}$ The half-lives in water and soils, however, often vary among and within compound classes (Figure 2D,E), which complicates the estimation of fungicide dissipation. For example, triazole fungicides (a group of DMI fungicides) contain compounds that are stable to hydrolytic degradation (e.g., penconazole and difenoconazole) as well as compounds that are quickly degraded (e.g., myclobutanil). ${ }^{40}$

Detection in Aquatic Systems. The coupling of frequent applications with moderate to high environmental persistence and mobility raises concerns about chronic exposure of biota in agricultural and urban surface water bodies. However, fungicide surface water exposure has received little attention compared to insecticides and herbicides. ${ }^{41,42}$ While a considerable number of small, localized studies contain quantitative data on fungicides in freshwater bodies, large scale (i.e., nationwide or continental) pesticide monitoring efforts in the U.S. and the EU have only given cursory consideration to a few fungicides. ${ }^{43,44}$ Moreover, many of these large scale monitoring studies focus on grab water samples only, which generally underestimate the number and concentrations of pesticides in streams. ${ }^{45,46}$ When analyzing the data set compiled for this review (see Supporting Information for details), chloronitriles, DMI fungicides (i.e., triazoles), and strobilurin fungicides constituted $41 \%$ of all observations (1090 concentrations of 46 fungicides; Table 1). For dithiocarbamates, in contrast, only limited observations were available (SI Table S1). Moreover, carboxamide (10\% of all observations) and organophosphate (9\%) fungicides were comparatively often detected, though detections were generally limited to North America and Asia, respectively (Table 1). Subdividing these data by continental origin additionally shows that mean concentrations were significantly lower in North America compared to all other continents (Wilcoxon rank sum test; $p<0.001)$. This is not an artifact of sampling effort (similar number of detections as in Europe; Figure 3), but may reflect a lower use on the landscape level as, for instance, fungicide use per harvested area is considerably lower in the U.S. compared to major European crop producing countries

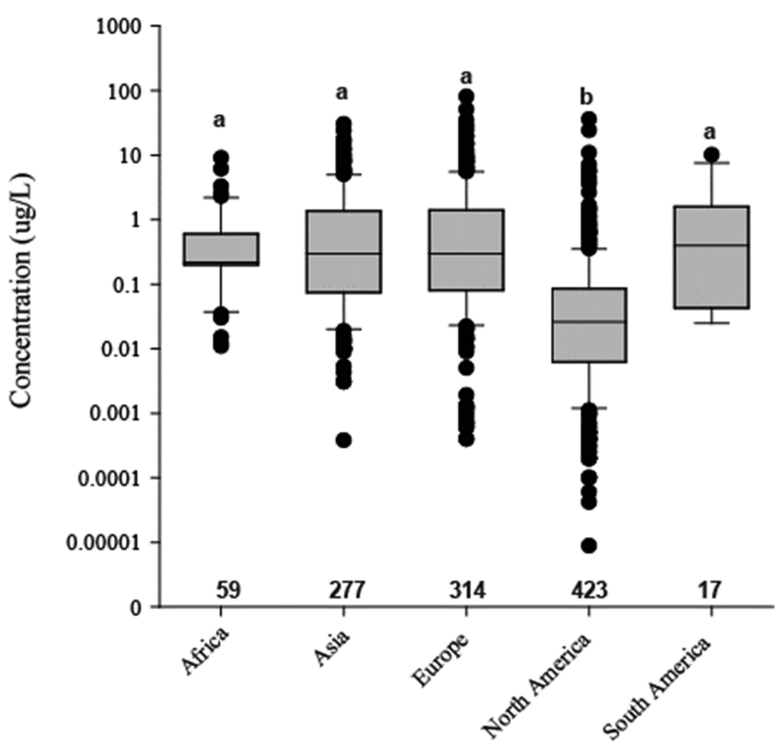

Figure 3. Boxplots of fungicide concentrations compiled from the literature (see SI Table S1 for details) separated by continent. Number of detections per continent are provided and different letters indicate statistical significance.

(e.g., France: factor 11; Germany: factor 7). ${ }^{3,15,47}$ Most sites were affected by multiple land-use types (e.g., agricultural streams often were additionally affected by urban sources), and the lack of quantitative information on the relative contributions of land-use types hampered an analysis of their relation with fungicide exposure.

Local and regional field studies have documented the widespread and worldwide occurrence of fungicides in both agricultural and urban surface waters (SI Table S1). These studies indicate that aquatic biota may be chronically exposed to low or moderate fungicide concentrations and exposure might be punctuated by much higher concentrations during storm events, especially in seasons and regions with intense or continuous fungicide use. For instance, throughout and after the growing season, fungicides were detected in up to $75 \%$ of U.S. streams draining soybean production areas, ${ }^{22,48}$ and virtually in all sediments sampled in areas with intense potato cultivation. $^{38}$ In several European countries, propiconazole, boscalid, and carbendazim were among the most frequently detected pesticides and commonly occurred in mixtures with 2-3 herbicides. ${ }^{45}$ Summarizing studies with comprehensive fungicide monitoring (including $\geq 5$ fungicides), detection frequencies in streamwater and sediments typically exceed $75 \%$ and extended up to $96 \%$ in catchments dominated by agriculture. $^{38,39,49,50}$ While fungicides are detected in agricultural streams throughout the year, ${ }^{51}$ highest concentrations in streamwater occur during the growing season, ${ }^{42}$ and highest concentrations in stream sediments occur postharvest. ${ }^{39}$ This indicates that fungicides may persist in stream systems (particularly in sediments) during periods with frequent fungicide use, thereby increasing exposure duration at low concentrations locally and potentially downstream, through sediment remobilization. Furthermore, similar to herbicides and insecticides, fungicide occurrence depends on stream hydrology and several studies report the highest fungicide concentrations during storm events where concentrations might exceed base flow concentrations by a factor of $10 .^{49,50,52}$ 
Table 2. Top-5 Studied Fungicide Groups for Each Organism Group ${ }^{a}$

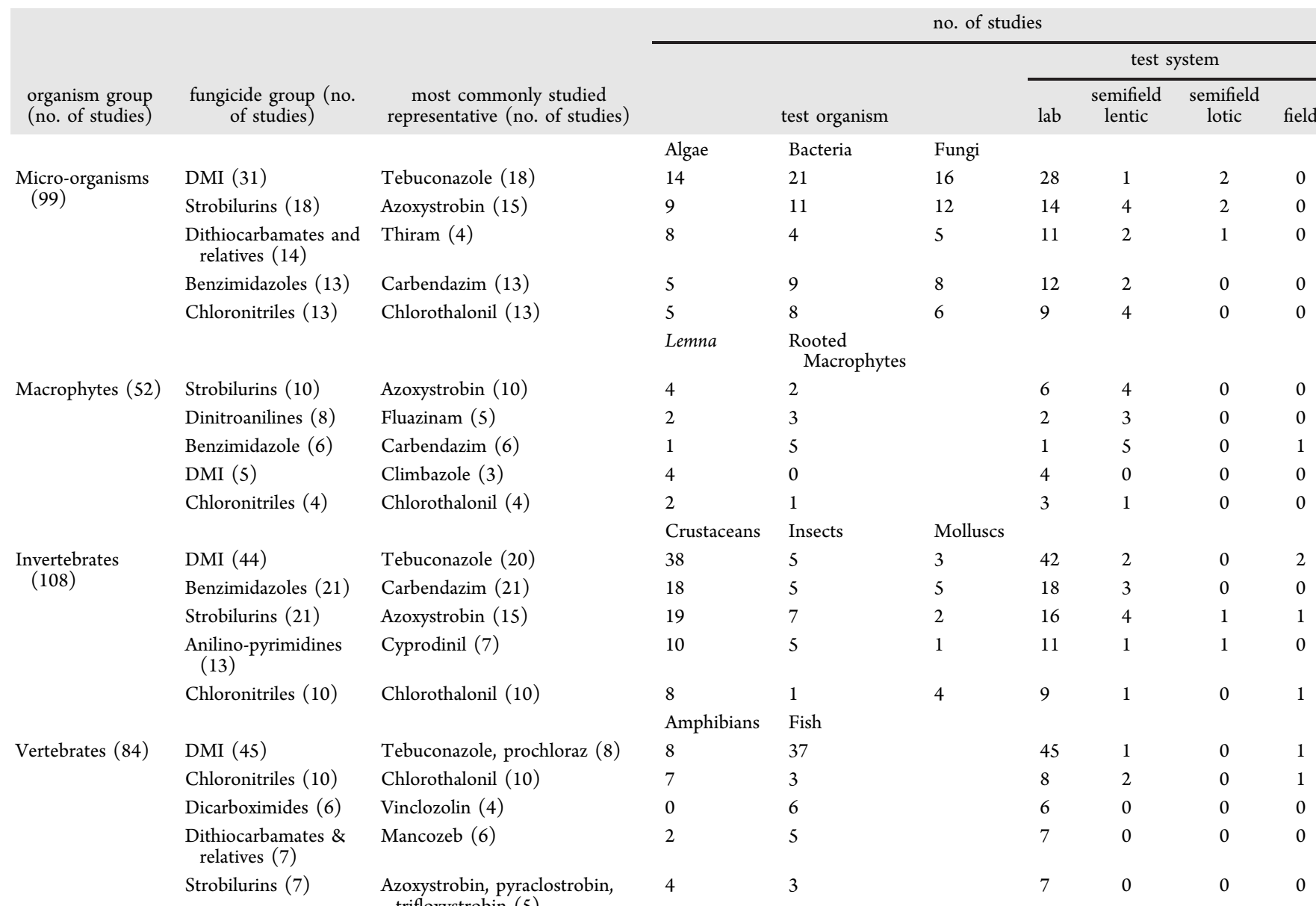

${ }^{a_{T}}$ The number of studies in this table account for $70 \%, 87 \%, 79 \%, 86 \%$ of papers identified for fungicide effects on aquatic microorganisms, macrophytes, invertebrates, and vertebrates, respectively. Note that multiple entries for one study were possible.

In European surface waters, higher median concentrations were observed for fungicides $(0.96 \mu \mathrm{g} / \mathrm{L} ; n=87 ; 23$ compounds) compared to those of herbicides $(0.063 \mu \mathrm{g} / \mathrm{L} ; n$ $=852 ; 36$ compounds $)$ and insecticides $(0.034 \mu \mathrm{g} / \mathrm{L} ; n=$ 1408; 59 compounds). ${ }^{53}$ This might be related to the persistence of many fungicides in the environment, application rates/scenarios, and/or spatial patterns of their agricultural use in the landscape. Accordingly, individual fungicides have been reported at concentrations exceeding $1 \mu \mathrm{g} / \mathrm{L}$ in streams during base flow, and sum concentrations of several dozen $\mu \mathrm{g} / \mathrm{L}$ were detected during runoff. ${ }^{8,50,54}$ While little information is available on fungicide exposure in ponds and lakes, fungicide concentrations of up to $6 \mu \mathrm{g} / \mathrm{L}$ in the water and $97 \mu \mathrm{g} / \mathrm{kg}$ in sediments have been reported for these systems. ${ }^{55,56}$ Compared to agricultural surface waters, the entry pathways and fate of fungicides in urban watersheds are even less understood. Fungicides in urban streams receiving wastewater effluents have been reported at sub $\mu \mathrm{g} / \mathrm{L}$ levels. ${ }^{32,57,58}$ However, in a study on 100 small streams across the U.S., fungicide concentrations of urban streams even exceeded those of agricultural streams. ${ }^{59}$

Exposure Modeling. During the prospective risk assessment of pesticides, exposure modeling is used to estimate predicted environmental concentrations (PECs) of compounds not yet authorized or under re-evaluation. ${ }^{60}$ Moreover, six studies used exposure modeling to calculate pesticide PECs in water bodies, employing water quality or leaching models relying on substance properties and environmental conditions. These studies indicate that under specific environmental conditions (worst-case soil conditions, heavy precipitation events), substantial amounts of fungicides can be transported into surface waters by surface runoff. ${ }^{61-63}$ Only three studies have compared fungicide PECs, based on different modeling approaches, with actual surface water concentrations: predicted runoff concentrations from a simple model (based mainly on soil, slope, precipitation) were in good agreement with concentrations measured in small lowland streams. ${ }^{64}$ In contrast, when applying realistic worst-case climate, soil, and landscape conditions, the predictions of the FOCUS (FOrum of the Coordination of pesticide fate models and their USe) modeling approach, which is used in the European ERA, underestimated up to $25 \%$ of the fungicide concentrations measured in European agricultural surface water bodies. ${ }^{41}$ The same was shown for two fungicides (i.e., chlorothalonil and cymoxanil) when concentrations measured in Portugal were compared to PECs calculated for the Mediterranean scenarios of the FOCUS approach. ${ }^{65}$

Mitigation of Exposure. Several technologies can mitigate pesticide input into aquatic systems via spray drift and runoff. ${ }^{66}$ Besides reducing the amount of applied fungicides, ${ }^{67}$ increasing the distance from surface water bodies to sprayed agricultural fields is among the most efficient mitigation 
measures for reducing pesticide transport to surface waters. ${ }^{66}$ The efficiency of nonsprayed buffer strips might be further increased by dense vegetation shielding surface water bodies from spray drift. However, only $25 \%$ of 104 sites exhibited a sufficiently dense vegetation during a survey within a vine growing region in Palatinate, Germany, ${ }^{68}$ where fungicides are heavily used. ${ }^{4}$ Buffer strips can also mitigate runoff from agricultural fields. ${ }^{67}$ A field study in Denmark indicated that the width of buffer strips was critical to predicting in-stream pesticide concentrations, ${ }^{69}$ which was likely driven by an infiltration of pesticide-contaminated water and sedimentation of pesticide-loaded soil particles. ${ }^{70}$ Along these lines, several studies reported erosion rills (i.e., preferential flow paths) to substantially reduce the mitigation potential of vegetated buffer strips for pesticide entry via runoff. ${ }^{8,71}$ For instance, erosion rills completely eliminated the effectiveness of a $52 \mathrm{~m}$ buffer strip. $^{72}$ Hence, buffer strips might be an efficient mitigation measure for pesticide (or fungicide) entry into surface water bodies in the absence of preferential flow paths and if their vegetation is properly managed to optimize both cover and density.

Once fungicides are released into a stream, vegetated ditches, (constructed) wetlands or, more generally, vegetated treatment systems (VTSs) are effective measures to reduce concentrations. $^{66,73}$ The efficiency of VTSs seems to depend on the physicochemical properties of the compound as well as system-inherent physical, hydrological and biogeochemical properties. $^{74}$ For example, the affinity of pesticides to organic carbon $\left(K_{\mathrm{oc}}\right)$, their half-life in water $\left(\mathrm{DT}_{50}\right)$, and the hydraulic retention time and plant density of the VTS were identified as variables determining the pesticide removal efficiency of VTSs. $^{74}$ Although data for more polar, water-soluble compounds (relevant for several fungicide groups) are limited, a recent field study indicates that similar VTS properties (e.g., plant density and size-related properties) control mitigation of peak fungicide exposures. ${ }^{75}$ Given the diversity and multitude of possible combinations of physicochemical properties of fungicides and VTS characteristics, removal efficiencies vary largely. ${ }^{76}$ Accordingly, several studies reported fungicide removal efficiencies via sorption to sediment or biodegradation in VTSs between 50 and $100 \%,{ }^{77,78}$ whereas only up to $10 \%$ of the applied fungicide load might be retained-passively or actively-by macrophytes, ${ }^{79}$ depending on their growth stage. $^{80}$

\section{EFFECTS}

We identified 99, 52, 108, and 84 relevant (see SI) studies dealing with fungicide effects on microorganisms, macrophytes, invertebrates, and vertebrates, respectively (Table 2). In most cases, the five most studied fungicide groups for all taxonomic groups were represented by the four major fungicide classes identified above plus the benzimidazoles, which played an important role in the past. ${ }^{81}$ The DMI fungicides always ranked first by organism group, except for macrophytes, where strobilurins were most frequently studied. Regarding microorganisms, the number of studies dealing with algae, bacteria, and fungi was relatively similar, whereas other microbial groups received hardly any attention (Table 2). For macrophytes, almost exclusively Lemna and rooted macrophytes were assessed. The data for invertebrates are strongly biased toward crustaceans (particularly Daphnia spp. and Gammarus spp.). Considerably fewer studies dealt with insects and molluscs, and studies dealing with other invertebrate groups are scant.
Regarding vertebrates, there are more studies on DMI and dicarboximide fungicide toxicity to fish than studies on amphibians, though numbers were more balanced for other fungicide groups (but see small $n$ ). For all organism and fungicide groups, most studies were conducted in the laboratory. Only a few semifield mesocosm studies were performed that mostly focused on lentic systems, and almost no field studies have been conducted (Table 2).

Direct Effects. We analyzed direct effects, defined as direct physiological or biochemical responses of an organism to toxicant exposure. Our analysis was confined to substance groups for which data on at least three of the four organism groups (i.e., microorganisms, macrophytes, invertebrates, and vertebrates) were available (i.e., the four major fungicide groups (DMIs, strobilurins, chloronitriles, and dithiocarbamates) and the benzimidazoles).

DMI Fungicides. The DMI fungicides contain several chemical groups, such as the triazoles and imidazoles, that share a common mode of action (MoA), namely to block the cytochrome P450 monooxygenases (CYP)-mediated step responsible for fungal ergosterol production and thus cell wall synthesis. ${ }^{9}$ This group contains compounds that can be highly toxic to microorganisms and impede ecosystem functioning, whereas acute toxicity in macrophytes, invertebrates, and vertebrates, in test systems, is relatively low (see Table 3 for terminology in this section). Regarding micro-

Table 3. Terminology Used to Classify Toxicity (Adapted from the Pesticide Properties DataBase ${ }^{40}$ )

\begin{tabular}{|c|c|}
\hline $\begin{array}{l}\text { concentration at which toxicity is } \\
\text { reported (in } \mathrm{mg} / \mathrm{L} \text { ) }\end{array}$ & terms used \\
\hline \multicolumn{2}{|l|}{ Acute Toxicity } \\
\hline$>100$ & $\begin{array}{l}\text { "low toxicity" or "toxic at high } \\
\text { concentrations" }\end{array}$ \\
\hline $0.1-100$ & $\begin{array}{l}\text { "moderate toxicity" or "toxic at } \\
\text { moderate concentrations" }\end{array}$ \\
\hline$<0.1$ & $\begin{array}{l}\text { "high toxicity" or "toxic at low } \\
\text { concentrations" }\end{array}$ \\
\hline \multicolumn{2}{|l|}{ Chronic Toxicity } \\
\hline$>10$ & $\begin{array}{l}\text { "low toxicity" or "toxic at high } \\
\text { concentrations" }\end{array}$ \\
\hline $0.01-10$ & $\begin{array}{l}\text { "moderate toxicity" or "toxic at } \\
\text { moderate concentrations" }\end{array}$ \\
\hline$<0.01$ & $\begin{array}{l}\text { "high toxicity" or "toxic at low } \\
\text { concentrations" }\end{array}$ \\
\hline
\end{tabular}

organisms, for instance, only 2 out of 10 tested algae and cyanobacteria species showed significant effects on ${ }^{14} \mathrm{C}$ uptake when exposed to moderate concentrations $(83 \mu \mathrm{g} / \mathrm{L})$ of the triazole propiconazole. ${ }^{82}$ By contrast, the triazoles tebuconazole and epoxiconazole were highly toxic (significant effects at $1 \mu \mathrm{g} / \mathrm{L})$ to aquatic fungi. ${ }^{83}$ Accordingly, triazoles were also found to affect important ecosystem functions. For instance, tebuconazole concentrations as low as $2 \mu \mathrm{g} / \mathrm{L}$ inhibited respiration and photosynthesis in heterotrophic and photoautotrophic biofilm and plankton communities. ${ }^{84}$ Moreover, a few studies showed effects on the functioning of microbial communities associated with decomposing leaf material. ${ }^{85-88}$

The imidazole climbazole retarded the growth of the aquatic plant L. minor (concentration resulting in $50 \%$ effect $\left(\mathrm{EC}_{50}\right)$ of $13 \mu \mathrm{g} / \mathrm{L}) .{ }^{89}$ This was attributed to a phytohormone imbalance linked to the biosynthesis of gibberellin.

Although DMI fungicides largely showed acute toxicity to invertebrates only at high concentrations (but see, e.g., Sisodia 
et al. ${ }^{90}$ ), sublethal effects such as altered food processing, lowered energy reserves as well as reduced growth and reproduction were partly observed at very low concentrations (i.e., in the (sub-) $\mu \mathrm{g} / \mathrm{L}$ range). ${ }^{91-93}$ The effects on growth and reproduction might result from energy being shunted toward detoxification of fungicides, but could also be triggered by an antiecdysteroid action as demonstrated for a variety of DMI fungicides. $^{94-96}$

The MoA of DMI fungicides is cause for concern for vertebrate toxicity because CYP isoforms are involved in the conversion of cholesterol to active sex steroids, biochemical pathways that are highly conserved among vertebrates. ${ }^{97}$ Although these fungicides can cause mortality and malformations (at about $\geq 5 \mathrm{mg} / \mathrm{L}$ ) and affect growth and development (at about $\geq 1 \mathrm{mg} / \mathrm{L}$ ), ${ }^{98}$ their most commonly reported effects on amphibians and fish is disruption of sex steroidogenesis and associated downstream effects on gonadal development, sex ratios, and fecundity. ${ }^{97,99,100}$

A specific feature of DMIs among fungicides is their potential to act as synergists in mixtures, likely by inhibiting CYP enzymes involved in phase I biotransformation of xenobiotics. ${ }^{101}$ Synergistic effects were partly demonstrated in microorganisms, for instance for Raphidocelis subcapitata when exposed to mixtures of ketoconazole and macrolide antibiotics. ${ }^{102}$ This was not confirmed for other mixtures (for instance exposing R. subcapitata and Vibrio fischeri to mixtures of prochloraz and other pesticides). ${ }^{101}$ While synergistic action of DMIs is not documented for macrophytes, it was shown for invertebrates such as D. magna and G. fossarum. ${ }^{101,103}$ DMIs' synergistic effects in invertebrates are substance-specific and only occur above lower threshold concentrations of the synergists. These thresholds decrease with exposure time. ${ }^{104}$ No studies examined the potential of DMI fungicides to produce synergistic effects in aquatic vertebrates.

Strobilurins. The strobilurins act by inhibiting the electron transfer from cytochrome $b$ to cytochrome $c_{1}$ in the fungal mitochondrial membrane. ${ }^{9}$ They can be highly toxic (Table 3 ) to all groups of organisms. In outdoor microcosm studies, pyraoxystrobin and azoxystrobin triggered transient effects in phytoplankton communities at 1 and $3.3 \mu \mathrm{g} / \mathrm{L}$, respectively. ${ }^{105,106}$ High toxicity of azoxystrobin is also reported for aquatic fungi, with no-observed effect concentrations (i.e., lowest concentrations for which no statistically significant effects were detected) for growth as low as $2 \mu \mathrm{g} / \mathrm{L} .{ }^{83}$ While community composition of leaf-associated fungi is reported to be affected at moderate azoxystrobin concentrations, functional effects in these communities seem to be triggered only by high concentrations of strobilurin fungicides. ${ }^{88,109}$

In the aquatic macrophyte Myriophyllum quitense, $50 \mu \mathrm{g} / \mathrm{L}$ of azoxystrobin caused oxidative stress and DNA damage. ${ }^{108}$ Apparently, these effects do not propagate to the population level as, for instance, no consistent, treatment-related effects were detected on the biomass of the rooted macrophyte species Elodea nuttallii in aquatic microcosms dosed with up to $33 \mu \mathrm{g} / \mathrm{L} .{ }^{106}$ However, for Chara globularis, a macro-algatransient declines in percentage of cover occurred at $3.3 \mu \mathrm{g} /$ L. ${ }^{106}$

Strobilurins were repeatedly shown to be moderately to highly toxic to aquatic invertebrates. For instance, the 96-h $\mathrm{LC}_{50}$ (concentration resulting in $50 \%$ mortality) of pyraclostrobin for $D$. magna was only $14 \mu \mathrm{g} / \mathrm{L},{ }^{109}$ and sublethal effects on respiration and reproduction in the same species were found at azoxystrobin concentrations as low as $0.026 \mu \mathrm{g} / \mathrm{L} .{ }^{110}$
Accordingly, strobilurins also trigger effects in invertebrate communities at low concentrations. Copepods reacted most sensitively to azoxystrobin with reductions in abundance at approximately $3 \mu \mathrm{g} / \mathrm{L}$ in brackish outdoor and indoor mesocosms as well as in freshwater outdoor mesocosms. ${ }^{106,111}$

Several studies that examined the effects of strobilurin fungicides on amphibians reported mortality at field-relevant concentrations. As an example, pyraclostrobin resulted in $100 \%$ mortality for tadpoles of Bufo cognatus at $1 /{ }_{10}$ the label rate for corn (corresponding to $15 \mu \mathrm{g} / \mathrm{L}) .^{112}$ Several studies also reported that strobilurins reduced growth and produced malformations. ${ }^{113-115}$ The only study addressing strobilurins' effects on the endocrine system deals with the effects of trifloxystrobin on medaka as a potential endocrine disruptor through affecting sex hormones and xenobiotic metabolism. ${ }^{116}$

Benzimidazoles. Benzimidazole fungicides inhibit microtubule assembly in fungal mitosis. ${ }^{9}$ While these fungicides seem to be mostly of low toxicity to aquatic microorganisms, macrophytes, and vertebrates, they can be highly toxic (Table 3 ) to invertebrates. As benzimidazoles are of low to moderate toxicity to algae, ${ }^{117}$ no direct effects on phytoplankton communities are reported in the literature. Similarly, carbendazim was of low toxicity to the eight aquatic fungal species tested by Dijksterhuis et al. ${ }^{83}$ and the 18 species tested by Chandrashekar \& Kaveriappa. ${ }^{118}$ Consequently, functioning of leaf-associated fungal communities was only affected at high concentrations. ${ }^{88,119}$ Both in an indoor microcosm study and an experimental ditch study using concentrations up to $1 \mathrm{mg} /$ $\mathrm{L}$, no direct toxicity of carbendazim to aquatic macrophytes was found. ${ }^{119,120}$

Carbendazim was moderately to highly toxic to most of the 11 invertebrate species tested by van Wijngaarden et al., with flatworms, oligochaetes, amphipods, and cladocerans being most sensitive. ${ }^{121}$ Accordingly, carbendazim was also moderately toxic to temperate and tropical (i.e., Thailand) zooplankton and macroinvertebrate communities in indoor microcosms and outdoor mesocosms, ${ }^{119,120,122}$ while Amazonian macroinvertebrates were in general much more tolerant to carbendazim exposure than their temperate relatives. ${ }^{123}$ Similarly, while carbendazim was of moderate to low toxicity to fish, Amazonian species appeared to be slightly less sensitive than temperate ones. ${ }^{123}$

Chlorothalonil. Chlorothalonil, a chloronitrile fungicide, is the most studied multisite fungicide, featuring several molecular target sites or MoAs. ${ }^{9}$ Chlorothalonil exhibits moderate to high toxicity (Table 3 ) to several organism groups, although acute toxicity to phytoplankton and invertebrates was rather low. While effects on individual species of algae were detected, ${ }^{124}$ the very few studies that assessed phytoplankton in mesocosm systems indicate negligible direct effects even at high concentrations, whereas reduction in leaf litter decomposition detected in these studies indicated negative effects on leaf-associated fungi. ${ }^{125,126}$ This is in agreement with very low concentrations $(0.02-1.8 \mu \mathrm{g} / \mathrm{L})$ inhibiting the growth of a fungus parasitizing amphibia (Batrachochytrium dendrobatidis; Bd), ${ }^{127}$ whereas no direct effects on zoonotic pathogens (Escherichia coli) and fecal indicator bacteria were found. ${ }^{128}$

Chlorothalonil displayed high toxicity to a range of macrophyte end points. ${ }^{129}$ Although direct effects on aquatic plants in single species tests (L. gibba) were observed, studies under more realistic conditions, including combined applica- 
tions (tank mixtures) and repeated application schedules, could not confirm these effects. ${ }^{124}$

Acute toxicity of chlorothalonil to invertebrates seems to be low to moderate, ${ }^{130,131}$ whereas sublethal behavioral and developmental effects occurred at very low concentrations. ${ }^{132,133}$ Moreover, most studies examining the effects of chlorothalonil exposure on aquatic vertebrates reported increased mortality at environmentally relevant concentrations, ${ }^{126,130,134,135}$ consistent with amphibian mortality events that were documented after chlorothalonil was applied to cranberry bogs. ${ }^{136}$ Several chlorothalonil studies also report reduced growth, developmental malformations, and alterations to immunity and organ integrity. ${ }^{134,137-139}$ Although few studies have explored the endocrine disrupting effects of chlorothalonil on aquatic vertebrates, several studies have reported nonmonotonic dose responses that might indicate endocrine disruption. ${ }^{127,134}$

Dithiocarbamates. Another relatively well studied compound group of multisite fungicides are the dithiocarbamates. In laboratory microcosms, nabam and thiram showed low to moderate toxicity (Table 3 ) toward algae and bacteria. ${ }^{140,141}$ Accordingly, effects on several phytoplankton species in outdoor mesocosms dosed with metiram occurred only at concentrations above $300 \mu \mathrm{g} / \mathrm{L}$, whereas no effects on the structure and functioning of leaf-associated fungal communities were detected, even at these high concentrations. ${ }^{142}$ This is consistent with very high effect thresholds of mancozeb for these fungi. ${ }^{118,143}$ Studies on dithiocarbamate toxicity toward macrophytes are lacking.

Crustaceans were relatively sensitive ( $48 \mathrm{~h} \mathrm{EC}_{50}$ between 10 and $20 \mu \mathrm{g} / \mathrm{L}$ ) toward thiram, and metiram in outdoor mesocosms transiently affected rotifers at $12 \mu \mathrm{g} / \mathrm{L} .^{141,142}$ Similarly, trophic niche width of freshwater gastropods was altered by a thiram concentration of $35 \mu \mathrm{g} / \mathrm{L}$. ${ }^{144}$ Moreover, mancozeb and maneb exposure have been reported to reduce survival, growth, and immunity, increase malformations and oxidative stress, and alter behavior in vertebrates in the $\mu \mathrm{g} / \mathrm{L}$ range. $^{145,146}$

Indirect Effects. Indirect fungicide effects, defined as effects mediated through another species/organism group that has been directly affected, have received far less attention than direct effects. This is because their study requires more complex test systems often involving multiple populations or communities and knowledge about the food web in the test system. Consequently, the deduction of indirect effects remains speculative in many cases. For microorganisms, an indirect effect reported by a few studies is an increase in phytoplankton abundance or biofilm biomass due to fungicide exposure. This effect was observed for fungicides covering a range of MoAs, including azoxystrobin, ${ }^{111}$ carbendazim, ${ }^{120,147}$ chlorothalonil, ${ }^{125,126}$ fluazinam (i.e., 2,6-dinitro-aniline), ${ }^{148}$ organochlorine fungicides (2,4,6-trichlorophenol and pentachlorophenol), ${ }^{149,150}$ and thiram. ${ }^{151}$ The pattern was linked to a reduced grazing pressure by affected invertebrate consumers or, as hypothesized by Staley et al., ${ }^{152}$ by microorganisms benefiting from the metabolization of fungicides or organic material set free by dying organisms. Less frequently, indirect effects mediated via interactions within microbial communities were reported. For instance, the reduction in a dominant diatom species in outdoor flow-through mesocosms dosed with $35 \mu \mathrm{g} / \mathrm{L}$ thiram increased diversity of diatom assemblages. ${ }^{151}$ Furthermore, the reduction of protozoan predators by exposure to chlorothalonil at $170 \mu \mathrm{g} / \mathrm{L}$ increased abundances of fecal indicator bacteria and microbial pathogens. ${ }^{153}$

Regarding macrophytes, a reduction in pathogenic pressure was considered responsible for the increased biomass of $E$. nuttallii in indoor microcosms at high carbendazim concentrations $(330$ and $1000 \mu \mathrm{g} / \mathrm{L}) .{ }^{19,120}$ However, this was not confirmed in a more complex ditch experiment (Gertie Arts, personal communication).

A few multispecies studies on invertebrates reported increases in certain zooplankton and macroinvertebrate taxa following fungicide exposure, potentially because of the loss of interacting species. Such effects are reported for carbendazim, ${ }^{119,120,147}$ metiram, and thiram, ${ }^{142,154}$ and pentachlorophenol. ${ }^{150}$ Studies focusing specifically on interactions between invertebrate species found additional evidence for indirect effects. For example, exploitative competition through rotifers alleviated effects of moderate carbendazim concentrations on Daphnia populations. ${ }^{155}$ Similarly, certain combinations of carbendazim concentrations and densities of the competitor Asellus aquaticus alleviated fungicide effects in G. pulex because of predation on the asselids. ${ }^{156}$ In contrast, predation success of the turbellarian Dendrocoelum lacteum on A. aquaticus was reduced when both were exposed to very high concentrations of tebuconazole (i.e., $1500 \mu \mathrm{g} / \mathrm{L}){ }^{157}$ Moreover, fungicide effects on leaf-associated microorganisms might alter food processing, as well as reduce energy reserves and survival in leaf-shredding invertebrates. ${ }^{86-88,93}$ In contrast, leaves from trees treated with systemic fungicides featured an increased resource quality for both aquatic microorganisms and invertebrates, which might be related to a reduced pressure of fungal infestations in treated plants allowing them to divert more energy and carbon from defense mechanisms to growth or energy storage. ${ }^{158}$

A few studies also showed indirect effects in aquatic vertebrates because of altered predator-prey interactions. For instance, exposure to the triazole fungicide myclobutanil at $10 \mu \mathrm{g} / \mathrm{L}$ increased predation rates on salmon, ${ }^{159}$ whereas sublethal exposure to the strobilurin fungicide trifloxystrobin $($ at $96-230 \mu \mathrm{g} / \mathrm{L})$ reduced predation rates on tadpoles. ${ }^{160}$ Moreover, fungicides can affect host-parasite interactions through toxicity to fungal pathogens of aquatic vertebrates, ${ }^{127}$ reducing fungal infections. ${ }^{161}$ However, many fungicides are also immunomodulators. ${ }^{134,137}$ Thus, their net effect on infection risk will depend on the strength and duration of both immunomodulation of the host and toxicity to the pathogen. ${ }^{134,137,162,163}$ For example, in cell cultures, low concentrations $(<0.57 \mu \mathrm{g} / \mathrm{L})$ of the fungicides azoxystrobin, chlorothalonil, and mancozeb were all directly toxic to the pathogenic fungus $\mathrm{Bd}$ that is implicated in worldwide amphibian declines. ${ }^{164}$ However, exposure of tadpoles to any of these fungicides at field relevant concentrations, even those used to control $\mathrm{Bd}$ infections, resulted in higher $\mathrm{Bd}$ abundances and greater Bd-induced mortality. ${ }^{164}$ Moreover, a field survey revealed that $\mathrm{Bd}$ prevalence was positively associated with concentrations of fungicides in ponds. ${ }^{164}$

\section{RISK OF FUNGICIDES TO AQUATIC ORGANISMS}

We showed that fungicides occur widely in aquatic systems and that they can be toxic for aquatic life. We evaluated their risks as the overlap of exposure and toxicity at the fungicide group level using field (SI Table S1) and effect concentrations from the peer-reviewed literature. Patchiness of data prohibited a comparison at the individual compound level. Our analysis 

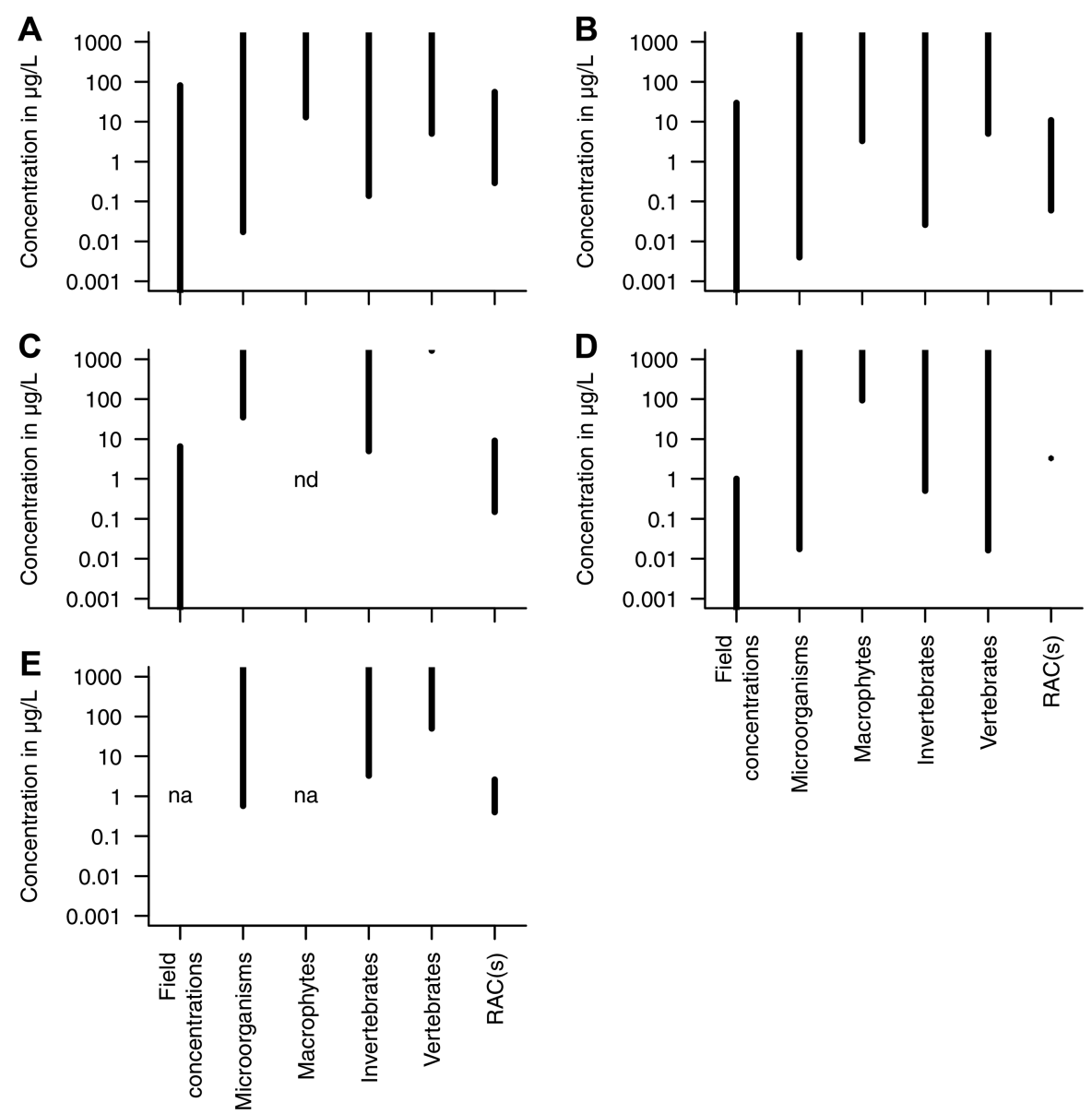

Figure 4. Overview of maximum detected global field concentrations (SI Table S1), toxicity to different organism groups according to the literature (including acute and chronic end points; SI Table S2), and regulatory acceptable concentrations (RACs; SI Table S3) derived during the EU's ERA for (A) demethylation inhibitors, (B) strobilurins, (C) benzimidazoles, (D) chloronitriles (i.e., chlorothalonil), and (E) dithiocarbamates. Field concentrations and toxicities are presented up to the highest detected concentrations and down to the lowest effect concentrations, respectively. $Y$ axis limit was set to 1000 , concentrations exceeding 1000 were cut. nd $=$ not detected; na $=$ not available.

revealed a considerable overlap of field and effect concentrations (including all levels of biological organization and both acute and chronic responses; see SI Table S2 for studies that contained lowest effect concentrations; Figure 4). The overlap was particularly large for DMI fungicides and strobilurins but was also evident for chloronitriles (i.e., chlorothalonil) and to a much lower degree the benzimidazoles. The absence of exposure data prohibited an evaluation for dithiocarbamates (see "Exposure" section). Note, however, that the solubility of chlorothalonil and dithiocarbamates in water is rather low (Figure 2), reducing the likelihood of chronic exposures that underlie some of the depicted effect concentrations (SI Table S2). Generally, microorganisms and invertebrates are most sensitive in each of the fungicide groups based on the lowest effect concentrations except in the chloronitriles group (chlorothalonil), where microorganisms and vertebrates are most sensitive (Table 2). Moreover, a considerable overlap with the regulatory acceptable concentrations (RACs) determined during the European ERA (SI Table S3) was evident for both field and effect concentrations. The frequent overlap of exposure and effects for single compounds (SI Tables S1, S2, and S3), though to a lower degree than on the group level, confirms that the concluded risks on the aggregated level (i.e., groups) are not an artifact.
The results of our analysis are supported by a comparison of field concentrations (SI Table S1) with standard toxicity data (i.e., acute data for algae, fish, and invertebrates) at the individual compound (substance) level. Within the ten substances for which the highest risk for adverse effects in aquatic ecosystems were indicated, three substances belong to the strobilurins (i.e., pyraclostrobin, azoxystrobin, and kresoxim-methyl) and two to the DMI fungicides (i.e., propiconazole and tebuconazole; Figure 5). Moreover, also the benzimidazole carbendazim and chlorothalonil rank among the substances of highest risk, indicating that representatives of the major fungicide groups are posing a risk to aquatic life (no assessment for dithiocarbamates because of limited data; see "Exposure" section). The reasons for the identified high risks and that current ERA practices are associated with RACs below field concentrations or above effect concentrations (Figures 4 and 5) are presumably manifold. Inter alia, the underestimation of field concentrations by exposure modeling (see "Exposure Modeling" section), the application of too small safety factors, ${ }^{165}$ the use of higher-tier ERA methods that can strongly increase RACs, ${ }^{88}$ and the noninclusion of most sensitive organisms (lowest effect concentrations often for fungi and fungal-like organisms; SI Table S2) in regulatory testing might have contributed to this situation. Risks were relatively similar across algae, fish, and invertebrates (range 9- 


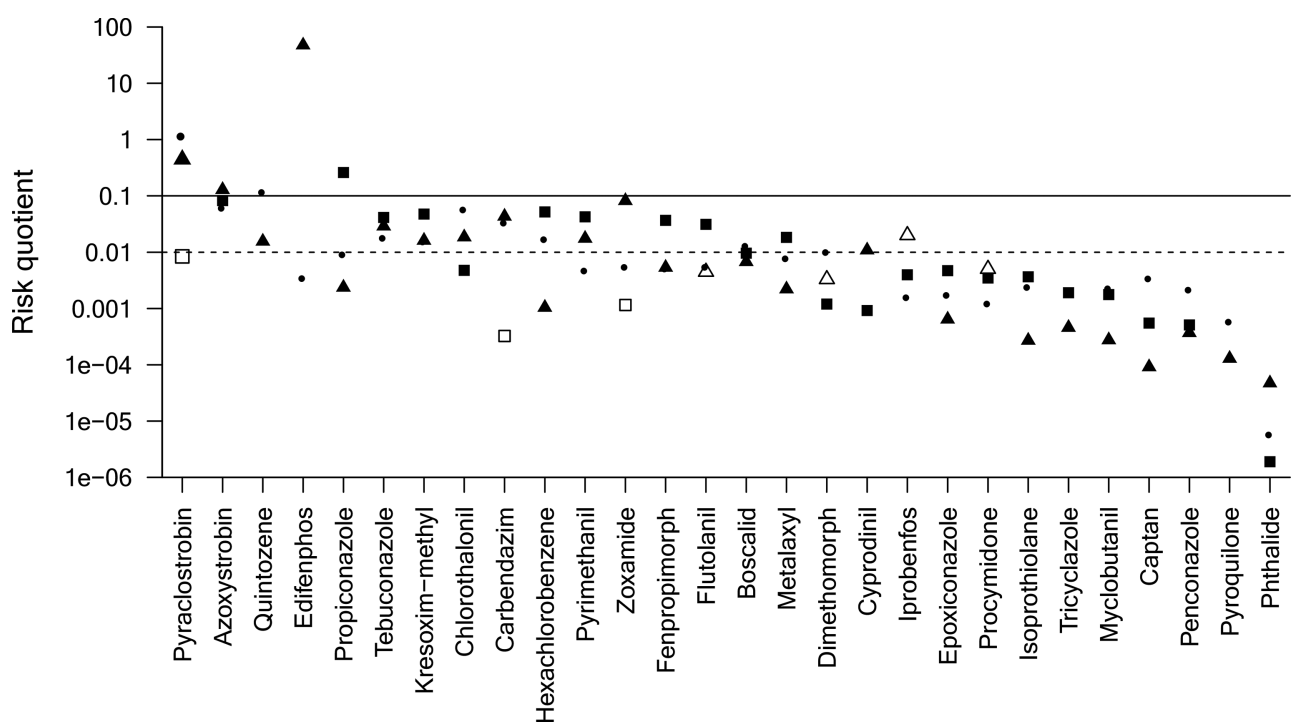

Figure 5. Risk quotients for algae (squares), fish (circles), and invertebrates (triangles) as ratios of maximum detected global field concentrations (SI Table S1; substances with $\geq 10$ observations) and acute standard toxicity data (i.e., the base set; provided by the Pesticide Properties DataBase $^{40}$ ). Open symbols indicate that toxicity was provided as "greater than" values. Risk quotients $>0.01$ (dashed line) and $>0.1$ (solid line) indicate moderate and high risks, respectively. Substances are ordered from highest to lowest risk according to the classification: high risk for several test organisms $>$ high risk for one test organism and moderate risk for two test organisms $>$ high risk for one test organism and moderate risk for one test organism $>$ high risk for one test organism $>$ moderate risk for three test organisms $>$ moderate risk for two test organisms $>$ moderate risk for one test organisms $>$ unclear risk (i.e., toxicity value provided as "greater than" value) $>$ all test organisms low risk. If substances scored equal, the mean risk quotient determined ranking. For risk quotients sorted by continent, see SI Table S4.

11) for the individual compound-level analysis, though high risks tended to occur more frequently for invertebrates than algae or fish (Figure 5). This confirms the elevated sensitivity for invertebrates identified during the analysis at the group level. Moreover, a comparison across continents showed most frequent risks for Europe (11 substances), followed by North America (6), Asia (4-5), Africa (3), and South America (2; see SI Table S4 for details). This situation might, however, not only mirror intensity of use but also monitoring efforts (see "Exposure" section; Figure 3).

\section{RESEARCH GAPS AND RECOMMENDATIONS FOR ERA}

We showed that fungicides occur widely in aquatic systems at concentrations that are associated with adverse effects on several groups of organisms (Figure 4), that the predictive accuracy of PECs is debatable, and that fungicide exposure can be effectively mitigated. We additionally demonstrated that fungicides can be highly toxic to a broad range of organisms and a high risk for aquatic biota was identified, for instance, for several representatives of the strobilurins and the DMI fungicides (Figures 4 and 5). Below, we outline central research gaps that currently challenge our ability to predict fungicide exposure and effects, promising research avenues, and shortcomings of the current ERA procedures to assess fungicide risks:

1. Environmental Sampling to Fully Capture Fungicide Exposure. Most available nationwide or continental pesticide monitoring efforts have only given cursory consideration to a few fungicides, ${ }^{43,44}$ with little attention being paid to their persistence in sink compartments, such as sediments or biofilms. Moreover, these large-scale monitoring studies tend to only utilize grab water sampling, which likely underestimates exposure in aquatic systems. ${ }^{45,46}$ For a more reliable estimation of longer-term fungicide exposure, other methods, such as sediment sampling (bed and suspended), event-driven sampling, for instance during runoff events, and deployment of passive samplers, could be more frequently included in large-scale monitoring efforts (for a program including many of these methods, see the Regional Stream Quality Assessment by USGS; https://webapps.usgs.gov/rsqa). ${ }^{166}$ Mixtures of fungicides were frequently detected in sediment samples, ${ }^{39,46,50}$ thereby indicating that sediments deserve continued attention, and the persistence and effects therein warrant investigation. These efforts would add valuable information on the duration and magnitude of fungicide exposure to aquatic organisms throughout the year in both agricultural and urban environments. Another path of fungicide exposure to aquatic organisms is through their food (e.g., algae, biofilms, detritus), but the contribution of exposure through this pathway has received little attention. Identifying all pathways of environmental exposure over a longer time frame would allow for more realistic exposure modeling and aid in determining successful mitigation strategies to limit exposure and overall risk to aquatic organisms. Furthermore, more emphasis should be given to the characterization of land use (including in upstream catchments) in monitoring studies to allow for analysis of the importance of land-use types for fungicide transport to surface waters. Finally, orienting fungicide monitoring toward high use substances is warranted. In this context, the absence of reliable data for a widely used fungicide group, namely the dithiocarbamates (see "Exposure" section), would need to be remedied to allow for a comprehensive picture of the risks posed by fungicides.

2. Tracing and Predicting the Fate of Fungicides in the Environment. A major gap currently challenging the assessment of fungicide exposure and effects is the limited understanding of these substances' fate in the environment. ${ }^{167}$ Using conventional approaches based on concentration measurements, dissipation processes can hardly be distin- 
guished, because a decrease in concentration might also be caused by nondegradative processes (i.e., dilution, volatilization, sorption). Therefore, novel approaches, such as compound-specific isotope analysis or suspect/nontarget analysis of transformation products, ${ }^{168}$ may enhance the identification of fungicide sources and transformation mechanisms. In addition, chiral fungicides (i.e., substances with at least two enantiomers, which are nonsuperimposable mirror images of each other) constitute a substantial portion of fungicides used worldwide. Although enantiomers have identical physicochemical properties, they may display different toxicity levels and degradation rates, and knowledge of enantioselective degradation of chiral fungicides remains scarce, rendering novel approaches to evaluate the fate of chiral pesticides necessary. ${ }^{169,170}$ Ultimately, information on isotopic and/or enantiomeric fractionation might feed into catchment and river reactive transport models to improve prediction of fungicide fate under variable environmental conditions. ${ }^{171,172}$ Such improvements in predicting fungicide fate seem necessary as the few studies on fungicide exposure predictions clearly show that the FOCUS modeling approach, used within the regulatory risk assessment of the EU, does not provide estimations that reflect actual field exposure to fungicides. $^{41,65}$ As this might indicate that actual environmental risk of fungicides is underestimated, also further targeted analyses of parameters and scenarios of the FOCUS approach are needed. Furthermore, studies comparing fungicide PECs generated by the U.S. Environmental Protection Agency's exposure modeling approach (i.e., Pesticide in Water Calculator; https://www.epa.gov/ceam/ surface-water-models-assess-exposures) with actual surface water concentrations are required to test for the protectivity of these estimates.

3. Promoting Complementary Mitigation Measures. To reduce the input of fungicides into surface waters and the associated risks, taxation of pesticides, in particular of the most hazardous molecules (e.g., pyraclostrobin and azoxystrobin; as identified in the "Risk of Fungicides to Aquatic Organisms" section), might help to limit applied fungicide amounts, foster agricultural alternatives to pesticides, and steer consumer behavior toward more environmentally friendly products (as suggested by Skevas et al. ${ }^{173}$ ). Replacing the most hazardous fungicides with more environmentally friendly alternatives might be seen as a complementary and necessary measure toward more sustainable agricultural practices. ${ }^{174}$ Understanding potentially unwanted side effects of such a development might require detailed monitoring, assessment, and management of these alternative compounds integrating feedback from all involved stakeholders. Moreover, although buffer strips and VTSs seem promising to reduce fungicide loads in water bodies, it remains unclear how these systems should be designed, positioned on the landscape, and managed to optimize their fungicide retention potential. Monitoring and predicting the efficiency of managed buffer strips and VTSs over the lifespan of the systems and for a wide variety of fungicides and hydrological conditions will yield knowledge that helps to adapt these off-crop measures to changes in agricultural practice (e.g., crop rotation).

4. Consideration and Exploitation of Aquatic Fungi. Data remain insufficient for many fungicide groups, hampering the evaluation of sensitivities of various taxonomic groups. While targeted research is required to fill these gaps, a high risk of fungicide toxicity was commonly indicated for aquatic fungi (see "Direct Effects" and "Risk of Fungicides to Aquatic Organisms" sections). Given their important roles in ecosystem processes, ${ }^{175}$ the fact that ERA ignores fungi is disconcerting and warrants reconsideration, particularly in the light of policy goals, such as the protection of ecosystem services to which they contribute. ${ }^{176,177}$ First developments of robust single-species tests are arising that could be included in ERA testing schemes. ${ }^{178-180}$ Moreover, in the past, the interpretation of multispecies experiments or field monitoring with aquatic fungi has been compromised by, among other things, their challenging morphological identification. DNAbased methods such as metabarcoding and species- or groupspecific quantitative real-time polymerase chain reaction provide tools for taxonomic identification and biomass quantification. $^{181,182}$ In addition, these methods offer new possibilities for solving major issues in stress and community ecology. Given their short generation times and small size, fungi are ideal model organisms to develop microcosm or field enclosure experiments to assess selection, adaptation, and their interaction with dispersal processes in (microbial) food webs.

5. Stronger Focus on Indirect Effects. Despite their potential to propagate to the functional level, indirect fungicide effects have received little attention compared to direct effects, which might be partly attributable to the difficulties to detect them and discriminate them from the latter. ${ }^{183-185}$ Recent progress in proteomics and metabolomics, however, enables the clear identification of toxic effects, and in turn the identification and quantification of indirect implications. ${ }^{186,187}$ Moreover, stable isotope analysis might support the identification of indirect effects through reconstructing food webs within test systems, ${ }^{188,189}$ while potential shifts in isotope signatures due to toxicity need to be considered. ${ }^{190}$ Given their sensitivity and the important roles they play in food webs, toxic effects in fungi seem prone to trigger indirect effects via both vertical (e.g., control of algae populations by chytrid fungi ${ }^{191}$ ) and horizontal (e.g., tolerant species benefiting from a release from fungicide-sensitive competitors; see "Indirect Effects" section) interactions. Moreover, insights into potential indirect fungicide effects mediated via the gut microbiome are lacking. These effects might underlie many of the physiological effects of fungicides in invertebrates and vertebrates. ${ }^{192,193}$ Because indirect effects can propagate through bottom-up or top-down effects in food webs, ${ }^{183}$ more testing at higher levels of organization seems required to identify effects that might remain undetected otherwise.

6. Considering Environmental Variation and Field Complexity. Current fungicide ERA tries to capture ignored ecological processes and environmental (i.e., variable environmental conditions and additional anthropogenic stressors) and management (i.e., pesticide use pattern in the upstream catchment) contexts via safety factors. ${ }^{194,195}$ However, little effort has been made to validate if safety factors sufficiently compensate for these processes and contexts. For instance, only a few studies have tested for the modulation of fungicide toxicity by environmental conditions, such as medium composition, ${ }^{83,91}$ temperature, ${ }^{196}$ or food availability, ${ }^{197,198}$ which generally pointed to stronger effects under suboptimal conditions. Moreover, to ultimately test the protectiveness of RACs, more field studies, complemented by laboratory experiments to prove causality of field associations, are required. ${ }^{199,200}$ Ideally, such investigations would span different climatic regions and different exposure histories because both the biogeographic region (demonstrated for carbenda- 
$\operatorname{zim}^{119,123}$ ) and previous exposure to fungicides (demonstrated for tebuconazole ${ }^{84}$ and a fungicide mixture ${ }^{201}$ ) can affect community sensitivities. ${ }^{202}$ This approach would allow researchers to test if observed effect patterns are contextdependent, requiring system- or region-specific risk assessments.

7. Increased Use of Effect Modeling. The empirical testing of all species (or species assemblages) to even single fungicides, let alone considering mixtures and the environmental and management context, is unfeasible under current conditions. ${ }^{203}$ Thus, scientific studies should strive to identify general findings at different levels of biological organization. $^{204,205}$ Moreover, effect modeling is a promising tool to predict missing data. For example, toxicokinetic-toxicodynamic modeling based on acute mortality data provided protective predictions for fungicide effects under time-varying exposure. $^{206}$ Furthermore, multispecies quantitative structuretoxicity relation modeling predicted the toxicity of fungicides in 20 invertebrate and vertebrate indicator species with considerable precision. ${ }^{207}$ However, despite these auspicious results, studies modeling fungicide effects are scarce. Therefore, an increase in effect modeling efforts is warranted to predict toxicity under variable environmental conditions while reducing animal testing whenever possible.

\section{ASSOCIATED CONTENT}

\section{S Supporting Information}

The Supporting Information is available free of charge on the ACS Publications website at DOI: 10.1021/acs.est.8b04392.

Details on the literature review process as well as surface water concentrations, lowest effect concentrations, regulatory acceptable concentrations, and risk quotients of fungicides (PDF)

\section{AUTHOR INFORMATION}

\section{Corresponding Author}

*Phone: (+49) 6341280 31361; fax: (+49) 6341280 31326; e-mail: zubrod@uni-landau.de.

\section{ORCID}

Jochen P. Zubrod: 0000-0001-9642-2205

Sylvain Payraudeau: 0000-0003-2546-7857

Kelly Smalling: 0000-0002-1214-4920

Ralf B. Schäfer: 0000-0003-3510-1701

\section{Notes}

The authors declare no competing financial interest.

\section{ACKNOWLEDGMENTS}

We acknowledge support by EU-INTERREG V Upper Rhine via project 1.6 SERIOR (SEcurity-RIsk-ORientation), the Swedish Research Council for Sustainable Development (FORMAS; Grant/Award Number: 942-2015-1568), the Carlsberg Foundation (Grant Number 2013_01_0833), and the U.S. Geological Survey Toxic Substances Hydrology Program, the National Science Foundation (EF-1241889), the National Institutes of Health (R01GM109499, R01TW010286), the U.S. Department of Agriculture (NRI 2006-01370, 2009-35102-0543), and the U.S. Environmental Protection Agency (CAREER 83518801). We thank Dr. Michael Gross and two anonymous reviewers for comments on an earlier version of this manuscript. Any use of trade, firm or product names is for descriptive purposes only and does not imply endorsement by the U.S. Government.

\section{ABBREVIATIONS}

\begin{tabular}{|c|c|}
\hline $\mathrm{Bd}$ & Batrachochytrium dendrobatidis \\
\hline CYP & cytochrome $\mathrm{P} 450$ \\
\hline DMI & demethylation inhibitor \\
\hline $\mathrm{DT}_{50}$ & $50 \%$ dissipation time (half-life) \\
\hline $\mathrm{EC}_{50} / \mathrm{LC}_{50}$ & concentrations resulting in $50 \%$ effect or mortality \\
\hline ERA & environmental risk assessment \\
\hline EU & European Union \\
\hline FOCUS & $\begin{array}{l}\text { Forum of the Coordination of Pesticide Fate } \\
\text { Models and Their Use }\end{array}$ \\
\hline$K_{\mathrm{oc}} / K_{\mathrm{ow}}$ & $\begin{array}{l}\text { partition coefficients between organic carbon/ } \\
\text { octanol and water }\end{array}$ \\
\hline MoA & mode of action \\
\hline PEC & predicted environmental concentration \\
\hline $\mathrm{RAC}$ & regulatory acceptable concentration \\
\hline U.S. & United States \\
\hline USGS & United States Geological Survey \\
\hline VTS & vegetated treatment systems \\
\hline
\end{tabular}

\section{REFERENCES}

(1) Fisher, M. C.; Henk, D. A.; Briggs, C. J.; Brownstein, J. S.; Madoff, L. C.; McCraw, S. L.; Gurr, S. J. Emerging fungal threats to animal, plant and ecosystem health. Nature 2012, 484 (7393), 186194.

(2) Strange, R. N.; Scott, P. R. Plant disease: a threat to global food security. Annu. Rev. Phytopathol. 2005, 43, 83-116.

(3) Eurostat Pesticide sales. http://appsso.eurostat.ec.europa.eu/ nui/show.do?dataset=aei_fm_salpest09.

(4) Roßberg, D., NEPTUN 2009 - Weinbau. Berichte aus der BBA 2009, 151.

(5) Hakala, K.; Hannukkala, A. O.; Huusela-Veistola, E.; Jalli, M.; Peltonen-Sainio, P. Pests and diseases in a changing climate: a major challenge for Finnish crop production. Agric. Food Sci. 2011, 20, 314.

(6) Boxall, A. B.; Hardy, A.; Beulke, S.; Boucard, T.; Burgin, L.; Falloon, P. D.; Haygarth, P. M.; Hutchinson, T.; Kovats, R. S.; Leonardi, G.; Levy, L. S.; Nichols, G.; Parsons, S. A.; Potts, L.; Stone, D.; Topp, E.; Turley, D. B.; Walsh, K.; Wellington, E. M.; Williams, R. $\mathrm{J}$. Impacts of climate change on indirect human exposure to pathogens and chemicals from agriculture. Environ. Health Perspect. 2009, 117 (4), 508-514.

(7) Kahle, M.; Buerge, I. J.; Hauser, A.; Müller, M. D.; Poiger, T. Azole fungicides: occurrence and fate in wastewater and surface waters. Environ. Sci. Technol. 2008, 42 (19), 7193-7200.

(8) Bereswill, R.; Golla, B.; Streloke, M.; Schulz, R. Entry and toxicity of organic pesticides and copper in vineyard streams: erosion rills jeopardise the efficiency of riparian buffer strips. Agric., Ecosyst. Environ. 2012, 146 (1), 81-92.

(9) Stenersen, J. Chemical Pesticides Mode of Action and Toxicology; CRC Press: Boca Raton, 2004.

(10) Maltby, L.; Brock, T. C. M.; van den Brink, P. J. Fungicide risk assessment for aquatic ecosystems: importance of interspecific variation, toxic mode of action, and exposure regime. Environ. Sci. Technol. 2009, 43 (19), 7556-7563.

(11) Köhler, H. R.; Triebskorn, R. Wildlife ecotoxicology of pesticides: can we track effects to the population level and beyond? Science 2013, 341 (6147), 759-765.

(12) Kiaune, L.; Singhasemanon, N., Pesticidal copper (I) oxide: environmental fate and aquatic toxicity. In Reviews of Environmental Contamination and Toxicology, Springer: 2011; Vol. 213, pp 1-26.

(13) Flemming, C. A.; Trevors, J. T. Copper toxicity and chemistry in the environment: a review. Water, Air, Soil Pollut. 1989, 44 (1), 143-158. 
(14) Research and Markets. Global Fungicides Market (Type, Crop Type and Geography - Size, Share, Global Trends, Company Profiles, Analysis, Segmentation and forecast, 2013-2020, 2014.

(15) USGS Pesticide National Synthesis Project. Preliminary Pesticide Us Estimates For 2016. https://water.usgs.gov/nawqa/ pnsp/usage/maps/county-level/.

(16) McCornack, B. P.; Ragsdale, D. W., Efficacy of thiamethoxam to suppress soybean aphid populations in Minnesota soybean. Arthropod Manage. Tests. 2006, 5, (1).

(17) Seagraves, M. P.; Lundgren, J. G. Effects of neonicitinoid seed treatments on soybean aphid and its natural enemies. J. Pest Sci. 2012, 85 (1), 125-132.

(18) Bonmatin, J.-M.; Giorio, C.; Girolami, V.; Goulson, D.; Kreutzweiser, D.; Krupke, C.; Liess, M.; Long, E.; Marzaro, M.; Mitchell, E. A. Environmental fate and exposure; neonicotinoids and fipronil. Environ. Sci. Pollut. Res. 2015, 22 (1), 35-67.

(19) Thompson, H. M. Risk assessment for honey bees and pesticides-recent developments and 'new issues'. Pest Manage. Sci. 2010, 66 (11), 1157-1162.

(20) Nettles, R.; Watkins, J.; Ricks, K.; Boyer, M.; Licht, M.; Atwood, L. W.; Peoples, M.; Smith, R. G.; Mortensen, D. A.; Koide, $\mathrm{R}$. T. Influence of pesticide seed treatments on rhizosphere fungal and bacterial communities and leaf fungal endophyte communities in maize and soybean. Appl. Soil Ecol. 2016, 102, 61-69.

(21) Lefrancq, M.; Imfeld, G.; Payraudeau, S.; Millet, M. Kresoxim methyl deposition, drift and runoff in a vineyard catchment. Sci. Total Environ. 2013, 442, 503-508.

(22) Reilly, T. J.; Smalling, K. L.; Orlando, J. L.; Kuivila, K. M. Occurrence of boscalid and other selected fungicides in surface water and groundwater in three targeted use areas in the United States. Chemosphere 2012, 89 (3), 228-234.

(23) Oerke, E.-C. Crop losses to pests. J. Agric. Sci. 2006, 144 (1), $31-43$.

(24) Avenot, H. F.; Michailides, T. J. Resistance to boscalid fungicide in Alternaria alternata isolates from pistachio in California. Plant Dis. 2007, 91 (10), 1345-1350.

(25) Ma, Z.; Felts, D.; Michailides, T. J. Resistance to azoxystrobin in Alternaria isolates from pistachio in California. Pestic. Biochem. Physiol. 2003, 77 (2), 66-74.

(26) Van Den Bosch, F.; Paveley, N.; Shaw, M.; Hobbelen, P.; Oliver, $\mathrm{R}$. The dose rate debate: does the risk of fungicide resistance increase or decrease with dose? Plant Pathol. 2011, 60 (4), 597-606.

(27) van den Bosch, F.; Paveley, N.; van den Berg, F.; Hobbelen, P.; Oliver, R. Mixtures as a fungicide resistance management tactic. Phytopathology 2014, 104 (12), 1264-1273.

(28) Brent, K. J.; Hollomon, D. W. Fungicide Resistance: The Assessment of Risk, FRAC Monograph No 2, 2nd ed.; Fungicide Resistance Action Committee, 2007.

(29) Gerecke, A. C.; Schärer, M.; Singer, H. P.; Müller, S. R.; Schwarzenbach, R. P.; Sägesser, M.; Ochsenbein, U.; Popow, G. Sources of pesticides in surface waters in Switzerland: pesticide load through waste water treatment plants--current situation and reduction potential. Chemosphere 2002, 48 (3), 307-315.

(30) Burkhardt, M.; Zuleeg, S.; Vonbank, R.; Bester, K.; Carmeliet, J.; Boller, M.; Wangler, T. Leaching of biocides from facades under natural weather conditions. Environ. Sci. Technol. 2012, 46 (10), 5497-5503.

(31) Wittmer, I. K.; Scheidegger, R.; Stamm, C.; Gujer, W.; Bader, H.-P. Modelling biocide leaching from facades. Water Res. 2011, 45 (11), 3453-3460.

(32) Bollmann, U. E.; Tang, C.; Eriksson, E.; Jönsson, K.; Vollertsen, J.; Bester, K. Biocides in urban wastewater treatment plant influent at dry and wet weather: concentrations, mass flows and possible sources. Water Res. 2014, 60, 64-74.

(33) Wittmer, I.; Bader, H.-P.; Scheidegger, R.; Singer, H.; Lück, A.; Hanke, I.; Carlsson, C.; Stamm, C. Significance of urban and agricultural land use for biocide and pesticide dynamics in surface waters. Water Res. 2010, 44 (9), 2850-2862.
(34) Haith, D. A.; Duffany, M. W. Pesticide runoff loads from lawns and golf courses. J. Environ. Eng. 2007, 133 (4), 435-446.

(35) Wick, A.; Fink, G.; Ternes, T. A. Comparison of electrospray ionization and atmospheric pressure chemical ionization for multiresidue analysis of biocides, UV-filters and benzothiazoles in aqueous matrices and activated sludge by liquid chromatography-tandem mass spectrometry. J. Chromatogr. A 2010, 1217 (14), 2088-2103.

(36) Kronvang, B.; Laubel, A.; Larsen, S. E.; Friberg, N. Pesticides and heavy metals in Danish streambed sediment. Hydrobiologia 2003, $494(1-3), 93-101$.

(37) Castillo, L. E.; Ruepert, C.; Solis, E. Pesticide residues in the aquatic environment of banana plantation areas in the north Atlantic zone of Costa Rica. Environ. Toxicol. Chem. 2000, 19 (8), 1942-1950.

(38) Smalling, K. L.; Kuivila, K. M.; Orlando, J. L.; Phillips, B. M.; Anderson, B. S.; Siegler, K.; Hunt, J. W.; Hamilton, M. Environmental fate of fungicides and other current-use pesticides in a central California estuary. Mar. Pollut. Bull. 2013, 73 (1), 144-153.

(39) Smalling, K. L.; Reilly, T. J.; Sandstrom, M. W.; Kuivila, K. M. Occurrence and persistence of fungicides in bed sediments and suspended solids from three targeted use areas in the United States. Sci. Total Environ. 2013, 447C, 179-185.

(40) FOOTPRINT The FOOTPRINT Pesticide Properties Database. Database collated by the University of Hertfordshire as part of the EU-funded FOOTPRINT project (FP6-SSP-022704). www.eufootprint.org/ppdb.html.

(41) Knäbel, A.; Meyer, K.; Rapp, J.; Schulz, R. Fungicide field concentrations exceed FOCUS surface water predictions: urgent need of model improvement. Environ. Sci. Technol. 2014, 48, 455-463.

(42) Wightwick, A.; Bui, A.; Zhang, P.; Rose, G.; Allinson, M.; Myers, J.; Reichman, S.; Menzies, N.; Pettigrove, V.; Allinson, G. Environmental fate of fungicides in surface waters of a horticulturalproduction catchment in Southeastern Australia. Arch. Environ. Contam. Toxicol. 2012, 62 (3), 380-390.

(43) Gilliom, R. J.; Barbash, J. E.; Crawford, C. G.; Hamilton, P. A.; Martin, J. D.; Nakagaki, N.; Nowell, L. H.; Scott, J. C.; Stackelberg, P. E.; Thelin, G. P. Pesticides in the Nation'S Streams and Ground Water, 1992-2001; US Geological Survey, 2006.

(44) Malaj, E.; von der Ohe, P. C.; Grote, M.; Kuhne, R.; Mondy, C. P.; Usseglio-Polatera, P.; Brack, W.; Schäfer, R. B. Organic chemicals jeopardize the health of freshwater ecosystems on the continental scale. Proc. Natl. Acad. Sci. U. S. A. 2014, 111 (26), 9549-9554.

(45) Schreiner, V. C.; Szöcs, E.; Bhowmik, A. K.; Vijver, M. G.; Schäfer, R. B. Pesticide mixtures in streams of several European countries and the USA. Sci. Total Environ. 2016, 573, 680-689.

(46) Moschet, C.; Wittmer, I.; Simovic, J.; Junghans, M.; Piazzoli, A.; Singer, H.; Stamm, C.; Leu, C.; Hollender, J. How a complete pesticide screening changes the assessment of surface water quality. Environ. Sci. Technol. 2014, 48 (10), 5423-5432.

(47) Food and Agriculture Organization of the United Nations FAOSTAT - Crops data 2016. http://www.fao.org/faostat/en/\#data/ QC.

(48) Battaglin, W.; Sandstrom, M.; Kuivila, K.; Kolpin, D.; Meyer, M. Occurrence of azoxystrobin, propiconazole, and selected other fungicides in US streams, 2005-2006. Water, Air, Soil Pollut. 2011, 218 (1), 307-322.

(49) Rasmussen, J. J.; Wiberg-Larsen, P.; Baattrup-Pedersen, A.; Cedergreen, N.; McKnight, U. S.; Kreuger, J.; Jacobsen, D.; Kristensen, E. A.; Friberg, N. The legacy of pesticide pollution: An overlooked factor in current risk assessments of freshwater systems. Water Res. 2015, 84, 25-32.

(50) Lefrancq, M.; Jadas-Hécart, A.; La Jeunesse, I.; Landry, D.; Payraudeau, S. High frequency monitoring of pesticides in runoff water to improve understanding of their transport and environmental impacts. Sci. Total Environ. 2017, 587, 75-86.

(51) Nanos, T.; Boye, K.; Kreuger, J. Results from the Environmental Monitoring of Pesticides (in Swedish), Ekohydrologi; Swedish University of Agricultural Sciences, Uppsala,2012.

(52) Lefrancq, M.; Payraudeau, S.; Verdú, A. J. G.; Maillard, E.; Millet, M.; Imfeld, G. Fungicides transport in runoff from vineyard 
plot and catchment: contribution of non-target areas. Environ. Sci. Pollut. Res. 2014, 21 (7), 4871-4882.

(53) Stehle, S.; Schulz, R. Pesticide authorization in the EUenvironment unprotected? Environ. Sci. Pollut. Res. 2015, 22 (24), 19632-19647.

(54) Rabiet, M.; Margoum, C.; Gouy, V.; Carluer, N.; Coquery, M. Assessing pesticide concentrations and fluxes in the stream of a small vineyard catchment - effect of sampling frequency. Environ. Pollut. 2010, 158 (3), 737-748.

(55) Shiraishi, H.; Pula, F.; Otsuki, A.; Iwakuma, T. Behaviour of pesticides in Lake Kasumugaura. Sci. Total Environ. 1988, 72, 29-42.

(56) Yurtkuran, Z.; Saygi, Y. Assessment of pesticide residues in Karabogaz Lake from Kizilirmak Delta, Turkey. Bull. Environ. Contam. Toxicol. 2013, 91 (2), 165-170.

(57) Metcalfe, C. D.; Sultana, T.; Li, H.; Helm, P. A. Current-use pesticides in urban watersheds and receiving waters of western Lake Ontario measured using polar organic chemical integrative samplers (POCIS). J. Great Lakes Res. 2016, 42 (6), 1432-1442.

(58) Carpenter, K. D.; Kuivila, K. M.; Hladik, M. L.; Haluska, T.; Cole, M. B. Storm-event-transport of urban-use pesticides to streams likely impairs invertebrate assemblages. Environ. Monit. Assess. 2016, 188 (6), 345.

(59) Van Metre, P. C.; Alvarez, D. A.; Mahler, B. J.; Nowell, L.; Sandstrom, M.; Moran, P. Complex mixtures of pesticides in Midwest US streams indicated by POCIS time-integrating samplers. Environ. Pollut. 2017, 220, 431-440.

(60) Adriaanse, P. I.; Allen, R.; Gouy, V.; Hollis, J. M.; Honsang, J.; Jarvis, N.; Klein, M.; Layton, R.; Linders, J.; Schäfer, H.; Smeets, L.; Yon, D. Surface Water Models and EU registration of Plant Protection Products. Final Report of the Work of the Regulatory Modelling Working Group on Surface Water Models of Focus (Forum of the Coordination of Pesticide Fate Models and Their Use), 1997; pp 1-231.

(61) Deb, D. Estimating Environmental Exposure of Emerging Agricultural Contaminants Using Spatial Data Analysis and Geographic Information System; Purdue University, 2007.

(62) Wauchope, R. D.; Potter, T. L.; Culbreath, A. K., Relating field dissipation and laboratory studies through modeling: Chlorothalonil dissipation after multiple applications in peanuts. In Terrestrial Field Dissipation Studies; Arthur, E. L.; Barefoot, A. C.; Clay, V. E., Eds.; ACS Symposium Series, American Chemical Society: Washington, DC, 2003; p 287.

(63) Vincelli, P. Simulations of fungicide runoff following applications for turfgrass disease control. Plant Dis. 2004, 88 (4), 391-396.

(64) Berenzen, N.; Lentzen-Godding, A.; Probst, M.; Schulz, H.; Schulz, R.; Liess, M. A comparison of predicted and measured levels of runoff-related pesticide concentrations in small lowland streams on a landscape level. Chemosphere 2005, 58, 683-691.

(65) Pereira, A. S.; Daam, M. A.; Cerejeira, M. J. Evaluation of FOCUS surface water pesticide concentration predictions and risk assessment of field-measured pesticide mixtures-a crop-based approach under Mediterranean conditions. Environ. Sci. Pollut. Res. 2017, 24, 17394-17406.

(66) Reichenberger, S.; Bach, M.; Skitschak, A.; Frede, H.-G. Mitigation strategies to reduce pesticide inputs into ground-and surface water and their effectiveness; a review. Sci. Total Environ. 2007, 384 (1), 1-35.

(67) Destandau, F.; Imfeld, G.; Rozan, A. Regulation of diffuse pesticide pollution: combining point source reduction and mitigation in stormwater wetland (Rouffach, France). Ecological engineering 2013, 60, 299-308.

(68) Ohliger, R.; Schulz, R. Water body and riparian buffer strip characteristics in a vineyard area to support aquatic pesticide exposure assessment. Sci. Total Environ. 2010, 408 (22), 5405-5413.

(69) Rasmussen, J. J.; Baattrup-Pedersen, A.; Wiberg-Larsen, P.; McKnight, U. S.; Kronvang, B. Buffer strip width and agricultural pesticide contamination in Danish lowland streams: Implications for stream and riparian management. Ecol. Eng. 2011, 37 (12), 19901997.
(70) Chen, H.; Grieneisen, M. L.; Zhang, M. Predicting pesticide removal efficacy of vegetated filter strips: A meta-regression analysis. Sci. Total Environ. 2016, 548, 122-130.

(71) Bereswill, R.; Streloke, M.; Schulz, R. Current-use pesticides in stream water and suspended particles following runoff: exposure, effects, and mitigation requirements. Environ. Toxicol. Chem. 2013, 32 (6), 1254-1263.

(72) Stehle, S.; Dabrowski, J. M.; Bangert, U.; Schulz, R. Erosion rills offset the efficacy of vegetated buffer strips to mitigate pesticide exposure in surface waters. Sci. Total Environ. 2016, 545, 171-183.

(73) Schulz, R.; Peall, S. K. C. Effectiveness of a constructed wetland for retention of nonpoint-source pesticide pollution in the Lourens River Catchment, South Africa. Environ. Sci. Environ. Sci. Technol. 2001, 35 (2), 422-426.

(74) Stehle, S.; Elsaesser, D.; Gregoire, C.; Imfeld, G.; Niehaus, E.; Passeport, E.; Payraudeau, S.; Schäfer, R. B.; Tournebize, J.; Schulz, R. Pesticide risk mitigation by vegetated treatment systems: a metaanalysis. J. Environ. Qual. 2011, 40 (4), 1068-1080.

(75) Bundschuh, M.; Elsaesser, D.; Stang, C.; Schulz, R. Mitigation of fungicide pollution in detention ponds and vegetated ditches within a vine-growing area in Germany. Ecological Engineering 2016, 89, $121-130$.

(76) Vymazal, J.; Březinová, T. The use of constructed wetlands for removal of pesticides from agricultural runoff and drainage: a review. Environ. Int. 2015, 75, 11-20.

(77) Maillard, E.; Payraudeau, S.; Faivre, E.; Grégoire, C.; Gangloff, S.; Imfeld, G. Removal of pesticide mixtures in a stormwater wetland collecting runoff from a vineyard catchment. Sci. Total Environ. 2011, 409 (11), 2317-2324.

(78) Maillard, E.; Payraudeau, S.; Ortiz, F.; Imfeld, G. Removal of dissolved pesticide mixtures by a stormwater wetland receiving runoff from a vineyard catchment: an inter-annual comparison. Int. J. Environ. Anal. Chem. 2012, 92 (8), 979-994.

(79) Stang, C.; Elsaesser, D.; Bundschuh, M.; Ternes, T. A.; Schulz, R. Mitigation of biocide and fungicide concentrations in flow-through vegetated stream mesocosms. J. Environ. Qual. 2013, 42 (6), 18891895.

(80) Maillard, E.; Imfeld, G. 1. Pesticide mass budget in a stormwater wetland. Environ. Sci. Technol. 2014, 48 (15), 8603-8611.

(81) Eurostat. The Use of Plant Protection Products in the European Union - Data 1992-2003; Office for the Official Publications of the European Union: Luxemburg, 2007.

(82) Peterson, H. G.; Boutin, C.; Martin, P. A.; Freemark, K. E.; Ruecker, N. J.; Moody, M. J. Aquatic phyto-toxicity of 23 pesticides applied at expected environmental concentrations. Aquat. Toxicol. 1994, 28 (3-4), 275-292.

(83) Dijksterhuis, J.; van Doorn, T.; Samson, R.; Postma, J. Effects of seven fungicides on non-target aquatic fungi. Water, Air, Soil Pollut. 2011, 222 (1), 421-425.

(84) Artigas, J.; Pascault, N.; Bouchez, A.; Chastain, J.; Debroas, D.; Humbert, J. F.; Leloup, J.; Tadonleke, R. D.; ter Halle, A.; Pesce, S. Comparative sensitivity to the fungicide tebuconazole of biofilm and plankton microbial communities in freshwater ecosystems. Sci. Total Environ. 2014, 468, 326-336.

(85) Artigas, J.; Majerholc, J.; Foulquier, A.; Margoum, C.; Volat, B.; Neyra, M.; Pesce, S. Effects of the fungicide tebuconazole on microbial capacities for litter breakdown in streams. Aquat. Toxicol. 2012, 122-123 (0), 197-205.

(86) Bundschuh, M.; Zubrod, J. P.; Kosol, S.; Maltby, L.; Stang, S.; Düster, L.; Schulz, R. Fungal composition on leaf explains pollutantmediated indirect effects on amphipod feeding. Aquat. Toxicol. 2011, 104, 32-37.

(87) Rasmussen, J. J.; Monberg, R. J.; Baattrup-Pedersen, A.; Cedergreen, N.; Wiberg-Larsen, P.; Strobel, B.; Kronvang, B. Effects of a triazole fungicide and a pyrethroid insecticide on the decomposition of leaves in the presence or absence of macroinvertebrate shredders. Aquat. Toxicol. 2012, 118-119 (0), 54-61.

(88) Zubrod, J. P.; Englert, D.; Feckler, A.; Koksharova, N.; Konschak, M.; Bundschuh, R.; Schnetzer, N.; Englert, K.; Schulz, R.; 
Bundschuh, M. Does the current fungicide risk assessment provide sufficient protection for key drivers in aquatic ecosystem functioning? Environ. Sci. Technol. 2015, 49, 1173-1181.

(89) Richter, E.; Wick, A.; Ternes, T. A.; Coors, A. Ecotoxicity of climbazole, a fungicide contained in antidandruff shampoo. Environ. Toxicol. Chem. 2013, 32 (12), 2816-2825.

(90) Sisodia, A. V.; Bijoy, V. M.; Harikrishnan, M. Haematological assessment on toxicity of fungicide hexaconazole on post larvae of Macrobrachium rosenbergii (de Man). Fish. Technol. 2016, 53 (1), 6468.

(91) Gonzalez-Ortegon, E.; Blasco, J.; Le Vay, L.; Gimenez, L. A multiple stressor approach to study the toxicity and sub-lethal effects of pharmaceutical compounds on the larval development of a marine invertebrate. J. Hazard. Mater. 2013, 263, 233-238.

(92) Sancho, E.; Villarroel, M. J.; Ferrando, M. D. Assessment of chronic effects of tebuconazole on survival, reproduction and growth of Daphnia magna after different exposure times. Ecotoxicol. Environ. Saf. 2016, 124 (Supplement C), 10-17.

(93) Feckler, A.; Goedkoop, W.; Zubrod, J. P.; Schulz, R.; Bundschuh, M. Exposure pathway-dependent effects of the fungicide epoxiconazole on a decomposer-detritivore system. Sci. Total Environ. 2016, 571, 992-1000.

(94) Hassold, E.; Backhaus, T. Chronic toxicity of five structurally diverse demethylase-inhibiting fungicides to the crustacean Daphnia magna: A comparative assessment. Environ. Toxicol. Chem. 2009, 28 (6), 1218-1226.

(95) $\mathrm{Mu}, \mathrm{X}$.; LeBlanc, G. A. Environmental antiecdysteroids alter embryo development in the crustacean Daphnia magna. J. Exp. Zool. 2002, 292 (3), 287-292.

(96) Soetaert, A.; van der Ven, K.; Moens, L. N.; Vandenbrouck, T.; van Remortel, P.; De Coen, W. M. Daphnia magna and ecotoxicogenomics: Gene expression profiles of the anti-ecdysteroidal fungicide fenarimol using energy-, molting- and life stage-related cDNA libraries. Chemosphere 2007, 67 (1), 60-71.

(97) Mazur, C. S.; Kenneke, J. F. Cross-species comparison of conazole fungicide metabolites using rat and rainbow trout (Onchorhynchus mykiss) hepatic microsomes and purified human CYP 3A4. Environ. Sci. Technol. 2008, 42 (3), 947-954.

(98) Zhu, B.; Liu, L.; Gong, Y.-X.; Ling, F.; Wang, G.-X. Triazoleinduced toxicity in developing rare minnow (Gobiocypris rarus) embryos. Environ. Sci. Pollut. Res. 2014, 21 (23), 13625-13635.

(99) Ankley, G. T.; Jensen, K. M.; Durhan, E. J.; Makynen, E. A.; Butterworth, B. C.; Kahl, M. D.; Villeneuve, D. L.; Linnum, A.; Gray, L. E.; Cardon, M. Effects of two fungicides with multiple modes of action on reproductive endocrine function in the fathead minnow (Pimephales promelas). Toxicol. Sci. 2005, 86 (2), 300-308.

(100) Kinnberg, K.; Holbech, H.; Petersen, G. I.; Bjerregaard, P. Effects of the fungicide prochloraz on the sexual development of zebrafish (Danio rerio). Comp. Biochem. Physiol., Part C: Toxicol. Pharmacol. 2007, 145 (2), 165-170.

(101) Cedergreen, N.; Kamper, A.; Streibig, J. C. Is prochloraz a potent synergist across aquatic species? A study on bacteria, daphnia, algae and higher plants. Aquat. Toxicol. 2006, 78 (3), 243-252.

(102) Yamagishi, T.; Horie, Y.; Tatarazako, N. Synergism between macrolide antibiotics and the azole fungicide ketoconazole in growth inhibition testing of the green alga Pseudokirchneriella subcapitata. Chemosphere 2017, 174, 1-7.

(103) Zubrod, J. P.; Baudy, P.; Schulz, R.; Bundschuh, M. Effects of current-use fungicides and their mixtures on the feeding and survival of the key shredder Gammarus fossarum. Aquat. Toxicol. 2014, 150, 133-143.

(104) Bjergager, M. B. A.; Dalhoff, K.; Kretschmann, A.; Norgaard, K. B.; Mayer, P.; Cedergreen, N. Determining lower threshold concentrations for synergistic effects. Aquat. Toxicol. 2017, 182, 7990.

(105) Chen, L.; Song, Y. F.; Tang, B. H.; Song, X. Y.; Yang, H. R.; Li, B. Y.; Zhao, Y.; Huang, C. T.; Han, X.; Wang, S. Y.; Li, Z. L. Aquatic risk assessment of a novel strobilurin fungicide: A microcosm study compared with the species sensitivity distribution approach. Ecotoxicol. Environ. Saf. 2015, 120, 418-427.

(106) van Wijngaarden, R. P.; Belgers, J. D.; Zafar, M. I.; Matser, A. M.; Boerwinkel, M. C.; Arts, G. H. Chronic aquatic effect assessment for the fungicide azoxystrobin. Environ. Toxicol. Chem. 2014, 33, $2775-2785$.

(107) Willming, M. M.; Maul, J. D. Direct and indirect toxicity of the fungicide pyraclostrobin to Hyalella azteca and effects on leaf processing under realistic daily temperature regimes. Environ. Pollut. 2016, 211, 435-442.

(108) Garanzini, D. S.; Menone, M. L. Azoxystrobin causes oxidative stress and DNA damage in the aquatic macrophyte Myriophyllum quitense. Bull. Environ. Contam. Toxicol. 2015, 94 (2), 146-151.

(109) Ochoa-Acuña, H.; Bialkowski, W.; Yale, G.; Hahn, L. Toxicity of soybean rust fungicides to freshwater algae and Daphnia magna. Ecotoxicology 2009, 18 (4), 440-446.

(110) Warming, T. P.; Mulderij, G.; Christoffersen, K. S. Clonal variation in physiological responses of Daphnia magna to the strobilurin fungicide azoxystrobin. Environ. Toxicol. Chem. 2009, 28 (2), 374-380.

(111) Gustafsson, K.; Blidberg, E.; Elfgren, I. K.; Hellstrom, A.; Kylin, H.; Gorokhova, E. Direct and indirect effects of the fungicide azoxystrobin in outdoor brackish water microcosms. Ecotoxicology 2010, 19 (2), 431-444.

(112) Belden, J.; McMurry, S.; Smith, L.; Reilley, P. Acute toxicity of fungicide formulations to amphibians at environmentally relevant concentrations. Environ. Toxicol. Chem. 2010, 29 (11), 2477-2480.

(113) Hartman, E. A.; Belden, J. B.; Smith, L. M.; McMurry, S. T. Chronic effects of strobilurin fungicides on development, growth, and mortality of larval Great Plains toads (Bufo cognatus). Ecotoxicology 2014, 23 (3), 396-403.

(114) Hooser, E. A.; Belden, J. B.; Smith, L. M.; McMurry, S. T. Acute toxicity of three strobilurin fungicide formulations and their active ingredients to tadpoles. Ecotoxicology 2012, 21 (5), 1458-1464.

(115) Li, D.; Liu, M.; Yang, Y.; Shi, H.; Zhou, J.; He, D. Strong lethality and teratogenicity of strobilurins on Xenopus tropicalis embryos: Basing on ten agricultural fungicides. Environ. Pollut. 2016, 208, 868-874.

(116) Zhu, L.; Wang, H.; Liu, H.; Li, W. Effect of trifloxystrobin on hatching, survival, and gene expression of endocrine biomarkers in early life stages of medaka (Oryzias latipes). Environ. Toxicol. 2015, 30 (6), 648-655.

(117) Ma, J. Y.; Zheng, R. Q.; Xu, L. G.; Wang, S. F. Differential sensitivity of two green algae, Scenedesmus oblignus and Chlorella pyrenoidosa, to 12 pesticides. Ecotoxicol. Environ. Saf. 2002, 52 (1), $57-61$.

(118) Chandrashekar, K. R.; Kaveriappa, K. M. Effect of pesticides on sporulation and germination of conidia of aquatic hyphomycetes. $J$. Environ. Biol. 1994, 15 (4), 315-324.

(119) Cuppen, J. G.; Van den Brink, P. J.; Camps, E.; Uil, K. F.; Brock, T. C. Impact of the fungicide carbendazim in freshwater microcosms. I. Water quality, breakdown of particulate organic matter and responses of macroinvertebrates. Aquat. Toxicol. 2000, 48 (2-3), 233-250.

(120) Van den Brink, P. J.; Hattink, J.; Bransen, F.; Van Donk, E.; Brock, T. C. Impact of the fungicide carbendazim in freshwater microcosms. II. Zooplankton, primary producers and final conclusions. Aquat. Toxicol. 2000, 48 (2-3), 251-264.

(121) van Wijngaarden, R. P. A.; Crum, S. J. H.; Decraene, K.; Hattink, J.; van Kammen, A. Toxicity of Derosal (active ingredient carbendazim) to aquatic invertebrates. Chemosphere 1998, 37 (4), $673-683$

(122) Daam, M. A.; Satapornvanit, K.; Van den Brink, P. J.; Nogueira, A. I. A. Sensitivity of macroinvertebrates to carbendazim under semi-field conditions in Thailand: Implications for the use of temperate toxicity data in a tropical risk assessment of fungicides. Chemosphere 2009, 74 (9), 1187-1194.

(123) Rico, A.; Waichman, A. V.; Geber-Correa, R.; van den Brink, P. J. Effects of malathion and carbendazim on Amazonian freshwater 
organisms: comparison of tropical and temperate species sensitivity distributions. Ecotoxicology 2011, 20 (4), 625-634.

(124) Arts, G. H. P.; Buijse-Bogdan, L. L.; Belgers, J. D. M.; van Rhenen-Kersten, C. H.; van Wijngaarden, R. P. A.; Roessink, I.; Maund, S. J.; van den Brink, P. J.; Brock, T. C. M. Ecological impact in ditch mesocosms of simulated spray drift from a crop protection program for potatoes. Integr. Environ. Assess. Manage. 2006, 2 (2), $105-125$.

(125) Halstead, N. T.; McMahon, T. A.; Johnson, S. A.; Raffel, T. R.; Romansic, J. M.; Crumrine, P. W.; Rohr, J. R. Community ecology theory predicts the effects of agrochemical mixtures on aquatic biodiversity and ecosystem properties. Ecol. Lett. 2014, 17 (8), 932941.

(126) McMahon, T. A.; Halstead, N. T.; Johnson, S.; Raffel, T. R.; Romansic, J. M.; Crumrine, P. W.; Rohr, J. R. Fungicide-induced declines of freshwater biodiversity modify ecosystem functions and services. Ecol. Lett. 2012, 15 (7), 714-722.

(127) McMahon, T. A.; Romansic, J. M.; Rohr, J. R. Nonmonotonic and monotonic effects of pesticides on the pathogenic fungus Batrachochytrium dendrobatidis in culture and on tadpoles. Environ. Sci. Technol. 2013, 47 (14), 7958-7964.

(128) Staley, Z. R.; Senkbeil, J. K.; Rohr, J. R.; Harwood, V. J. Lack of direct effects of agrochemicals on zoonotic pathogens and fecal indicator bacteria. Appl. Environ. Microbiol. 2012, 78 (22), 81468150.

(129) Belgers, J.; Aalderink, G.; Van den Brink, P. Effects of four fungicides on nine non-target submersed macrophytes. Ecotoxicol. Environ. Saf. 2009, 72 (2), 579-584.

(130) Ernst, W.; Doe, K.; Jonah, P.; Young, J.; Julien, G.; Hennigar, $P$. The toxicity of chlorothalonil to aquatic fauna and the impact of its operational use on a pond ecosystem. Arch. Environ. Contam. Toxicol. 1991, 21 (1), 1-9.

(131) Key, P. B.; Meyer, S. L.; Chung, K. W. Lethal and sub-lethal effects of the fungicide chlorothalonil on three life stages of the grass shrimp, Palaemonetes pugio. J. Environ. Sci. Health, Part B 2003, 38 (5), 539-549.

(132) Bellas, J. Comparative toxicity of alternative antifouling biocides on embryos and larvae of marine invertebrates. Sci. Total Environ. 2006, 367 (2), 573-585.

(133) Hellou, J.; Cook, A.; Lalonde, B.; Walker, P.; Dunphy, K.; MacLeod, S. Escape and survival of Corophium volutator and Ilyanassa obsoleta exposed to freshwater and chlorothalonil. J. Environ. Sci. Health, Part A: Toxic/Hazard. Subst. Environ. Eng. 2009, 44 (8), 778790.

(134) McMahon, T. A.; Halstead, N. T.; Johnson, S.; Raffel, T. R.; Romansic, J. M.; Crumrine, P. W.; Boughton, R. K.; Martin, L. B.; Rohr, J. R. The fungicide chlorothalonil is nonlinearly associated with corticosterone levels, immunity, and mortality in amphibians. Environ. Health Perspect. 2011, 119 (8), 1098.

(135) Ghose, S. L.; Donnelly, M. A.; Kerby, J.; Whitfield, S. M. Acute toxicity tests and meta-analysis identify gaps in tropical ecotoxicology for amphibians. Environ. Toxicol. Chem. 2014, 33 (9), 2114-2119.

(136) Winkler, E.; Potter, T.; Veneman, P. Chlorothalonil binding to aquatic humic substances assessed from gas purge studies. J. Environ. Sci. Health, Part B 1996, 31 (6), 1115-1170.

(137) Baier-Anderson, C.; Anderson, R. S. Evaluation of the immunotoxicity of chlorothalonil to striped bass phagocytes following in vitro exposure. Environ. Toxicol. Chem. 1998, 17 (8), 1546-1551.

(138) Méndez, M.; Obando, P.; Pinnock-Branford, M.; Ruepert, C.; Castillo, L. E.; Mena, F.; Alvarado, G. Acute, chronic and biochemical effects of chlorothalonil on Agalychnis callidryas, Isthmohyla pseudopuma and Smilisca baudinii tadpoles. Environ. Sci. Pollut. Res. 2016, 23 (21), 21238-21248.

(139) Yu, S.; Wages, M. R.; Cobb, G. P.; Maul, J. D. Effects of chlorothalonil on development and growth of amphibian embryos and larvae. Environ. Pollut. 2013, 181, 329-334.

(140) Ukeles, R. Growth of pure cultures of marine phytoplankton in the presence of toxicants. Appl. Microbiol. 1962, 10 (6), 532-537.
(141) Kyriakopoulou, K.; Anastasiadou, P.; Machera, K. Comparative toxicities of fungicide and herbicide formulations on freshwater and marine species. Bull. Environ. Contam. Toxicol. 2009, 82 (3), 290-295.

(142) Lin, R.; Buijse, L.; Dimitrov, M. R.; Dohmen, P.; Kosol, S.; Maltby, L.; Roessink, I.; Sinkeldam, J. A.; Smidt, H.; Van Wijngaarden, R. P.; Brock, T. C. Effects of the fungicide metiram in outdoor freshwater microcosms: responses of invertebrates, primary producers and microbes. Ecotoxicology 2012, 21 (5), 1550-1569.

(143) Chandrashekar, K. R.; Kaveriappa, K. M. Effect of pesticides on the growth of aquatic hyphomycetes. Toxicol. Lett. 1989, 48 (3), 311-315.

(144) Bayona, Y.; Roucaute, M.; Cailleaud, K.; Lagadic, L.; Basseres, A.; Caquet, T. Isotopic niche metrics as indicators of toxic stress in two freshwater snails. Sci. Total Environ. 2014, 484, 102-113.

(145) Gürkan, M.; Hayretdağ, S. Acute toxicity of maneb in the tadpoles of common and green toad. Arh. Hig. Rada Toksikol. 2015, 66 (3), 189-195.

(146) Shenoy, K.; Cunningham, B. T.; Enfroe, J. W.; Crowley, P. H. Growth and survival of northern leopard frog (Rana pipiens) tadpoles exposed to two common pesticides. Environ. Toxicol. Chem. 2009, 28 (7), 1469-1474.

(147) Daam, M. A.; Satapornvanit, K.; Van den Brink, P. J.; Nogueira, A. J. A. Direct and indirect effects of the fungicide carbendazim in tropical freshwater microcosms. Arch. Environ. Contam. Toxicol. 2010, 58 (2), 315-324.

(148) van Wijngaarden, R. P. A.; Arts, G. H. P.; Belgers, J. D. M.; Boonstra, H.; Roessink, I.; Schroer, A. F. W.; Brock, T. C. M. The species sensitivity distribution approach compared to a microcosm study: A case study with the fungicide fluazinam. Ecotoxicol. Environ. Saf. 2010, 73 (2), 109-122.

(149) Schauerte, W.; Lay, J. P.; Klein, W.; Korte, F. Influence of 2,4,6-trichlorophenol and pentachlorophenol on the biota of aquatic systems: Outdoor experiments in compartments of a natural pond. Chemosphere 1982, 11 (1), 71-79.

(150) Willis, K. J.; Van Den Brink, P. J.; Green, J. D. Seasonal variation in plankton community responses of mesocosms dosed with pentachlorophenol. Ecotoxicology 2004, 13 (7), 707-720.

(151) Bayona, Y.; Roucaute, M.; Cailleaud, K.; Lagadic, L.; Basseres, A.; Caquet, T. Structural and biological trait responses of diatom assemblages to organic chemicals in outdoor flow-through mesocosms. Environ. Pollut. 2014, 192, 186-195.

(152) Staley, Z. R.; Harwood, V. J.; Rohr, J. R. A synthesis of the effects of pesticides on microbial persistence in aquatic ecosystems. Crit. Rev. Toxicol. 2015, 45 (10), 813-836.

(153) Staley, Z. R.; Rohr, J. R.; Senkbeil, J. K.; Harwood, V. J. Agrochemicals indirectly increase survival of E. coli $\mathrm{O} 157: \mathrm{H} 7$ and indicator bacteria by reducing ecosystem services. Ecol. Appl. 2014, 24 (8), 1945-1953.

(154) Bayona, Y.; Roucaute, M.; Cailleaud, K.; Lagadic, L.; Basseres, A.; Caquet, T. Effect of thiram and of a hydrocarbon mixture on freshwater macroinvertebrate communities in outdoor stream and pond mesocosms: I. Study design, chemicals fate and structural responses. Ecotoxicology 2015, 24 (9), 1976-1995.

(155) Del Arco, A. I.; Rico, A.; van den Brink, P. J. Effects of intraand interspecific competition on the sensitivity of Daphnia magna populations to the fungicide carbendazim. Ecotoxicology 2015, 24 (6), 1362-1371

(156) Del Arco, A. I.; Parra, G.; Rico, A.; Van den Brink, P. J. Effects of intra- and interspecific competition on the sensitivity of aquatic macroinvertebrates to carbendazim. Ecotoxicol. Environ. Saf. 2015, $120,27-34$.

(157) Bundschuh, M.; Appeltauer, A.; Dabrunz, A.; Schulz, R. Combined effect of invertebrate predation and sublethal pesticide exposure on the behavior and survival of Asellus aquaticus (Crustacea; Isopoda). Arch. Environ. Contam. Toxicol. 2012, 63 (1), 77-85.

(158) Newton, K.; Zubrod, J. P.; Englert, D.; Luderwald, S.; Schell, T.; Baudy, P.; Konschak, M.; Feckler, A.; Schulz, R.; Bundschuh, M. The evil within? Systemic fungicide application in trees enhances litter 
quality for an aquatic decomposer-detritivore system. Environ. Pollut. 2018, 241, 549-556.

(159) Kruzynski, G.; Birtwell, I. A predation bioassay to quantify the ecological significance of sublethal responses of juvenile chinook salmon (Oncorhynchus tshawytscha) to the antisapstain fungicide TCMTB. Can. J. Fish. Aquat. Sci. 1994, 51 (8), 1780-1790.

(160) Junges, C.; Peltzer, P.; Lajmanovich, R.; Attademo, A.; Zenklusen, M. C.; Basso, A. Toxicity of the fungicide trifloxystrobin on tadpoles and its effect on fish-tadpole interaction. Chemosphere 2012, 87 (11), 1348-1354.

(161) Hanlon, S. M.; Kerby, J. L.; Parris, M. J. Unlikely remedy: fungicide clears infection from pathogenic fungus in larval southern leopard frogs (Lithobates sphenocephalus). PLoS One 2012, 7 (8), No. e43573.

(162) Rohr, J. R.; Raffel, T. R.; Sessions, S. K.; Hudson, P. J. Understanding the net effects of pesticides on amphibian trematode infections. Ecol. Appl. 2008, 18 (7), 1743-1753.

(163) Rohr, J. R.; Raffel, T. R.; Halstead, N. T.; McMahon, T. A.; Johnson, S. A.; Boughton, R. K.; Martin, L. B. Early-life exposure to a herbicide has enduring effects on pathogen-induced mortality. Proc. $R$. Soc. London, Ser. B 2013, 280 (1772), 20131502.

(164) Rohr, J. R.; Brown, J.; Battaglin, W. A.; McMahon, T. A.; Relyea, R. A. A pesticide paradox: Fungicides indirectly increase fungal infections. Ecol. Appl. 2017, 27, 2290-2302.

(165) Schäfer, R. B.; von der Ohe, P. C.; Rasmussen, J.; Kefford, B. J.; Beketov, M. A.; Schulz, R.; Liess, M. Thresholds for the effects of pesticides on invertebrate communities and leaf breakdown in stream ecosystems. Environ. Sci. Technol. 2012, 46, 5134-5142.

(166) Bundschuh, M.; Goedkoop, W.; Kreuger, J. Evaluation of pesticide monitoring strategies in agricultural streams based on the toxic-unit concept - Experiences from long-term measurements. Sci. Total Environ. 2014, 484, 84-91.

(167) Fenner, K.; Canonica, S.; Wackett, L. P.; Elsner, M. Evaluating pesticide degradation in the environment: blind spots and emerging opportunities. Science 2013, 341 (6147), 752-758.

(168) Elsner, M.; Imfeld, G. Compound-specific isotope analysis (CSIA) of micropollutants in the environment-current developments and future challenges. Curr. Opin. Biotechnol. 2016, 41, 60-72.

(169) Ulrich, E. M.; Morrison, C. N.; Goldsmith, M. R.; Foreman, W. T., Chiral pesticides: identification, description, and environmental implications. In Reviews of Environmental Contamination and Toxicology; Springer, 2012; Vol. 217, pp 1-74.

(170) Masbou, J.; Meite, F.; Guyot, B.; Imfeld, G. Enantiomerspecific stable carbon isotope analysis (ESIA) to evaluate degradation of the chiral fungicide Metalaxyl in soils. J. Hazard. Mater. 2018, 353, 99-107.

(171) Gaßmann, M.; Stamm, C.; Olsson, O.; Lange, J.; Kümmerer, K.; Weiler, M. Model-based estimation of pesticides and transformation products and their export pathways in a headwater catchment. Hydrol. Earth Syst. Sci. 2013, 17 (12), 5213.

(172) Lutz, S. R.; van der Velde, Y.; Elsayed, O. F.; Imfeld, G.; Lefrancq, M.; Payraudeau, S.; van Breukelen, B. M. Pesticide fate on catchment scale: conceptual modelling of stream CSIA data. Hydrol. Earth Syst. Sci. 2017, 21 (10), 5243.

(173) Skevas, T.; Oude Lansink, A. G. J. M.; Stefanou, S. E. Designing the emerging EU pesticide policy: A literature review. NJAS - Wageningen Journal of Life Sciences 2013, 64-65, 95-103.

(174) Berthoud, A.; Maupu, P.; Huet, C.; Poupart, A. Assessing freshwater ecotoxicity of agricultural products in life cycle assessment (LCA): a case study of wheat using French agricultural practices databases and USEtox model. Int. J. Life Cycle Assess. 2011, 16 (8), 841-847.

(175) Wong, M. K. M.; GohH, T.-K.; Hodgkiss, I. J.; Hyde, K. D.; Ranghoo, V. M.; Tsui, C. K. M.; Ho, W.-H.; Wong, W. S. W.; Yuen, T.-K. Role of fungi in freshwater ecosystems. Biodivers. Conserv. 1998, 7, 1187-1206.

(176) Nienstedt, K. M.; Brock, T. C.; van Wensem, J.; Montforts, M.; Hart, A.; Aagaard, A.; Alix, A.; Boesten, J.; Bopp, S. K.; Brown, C. Development of a framework based on an ecosystem services approach for deriving specific protection goals for environmental risk assessment of pesticides. Sci. Total Environ. 2012, 415, 31-38.

(177) European Commission. Our Life Insurance, Our Natural Capital: An EU Biodiversity Strategy to 2020; Communication from the Commission to the European Parliament, the Council, the Economic and Social Committee and the Committee of the Regions, 2011.

(178) Lategan, M. J.; Hose, G. C. Development of a groundwater fungal strain as a tool for toxicity assessment. Environ. Toxicol. Chem. 2014, 33, 2826-2834.

(179) Lategan, M. J.; Klare, W.; Kidd, S.; Hose, G. C.; Nevalainen, $\mathrm{H}$. The unicellular fungal tool RhoTox for risk assessments in groundwater systems. Ecotoxicol. Environ. Saf. 2016, 132, 18-25.

(180) Nagai, T., A novel, efficient, and ecologically relevant bioassay method using aquatic fungi and fungus-like organisms for fungicide ecological effect assessment. Environ. Toxicol. Chem. in press.2018371980

(181) Feckler, A.; Schrimpf, A.; Bundschuh, M.; Bärlocher, F.; Baudy, P.; Cornut, J.; Schulz, R. Quantitative real-time PCR as a promising tool for the detection and quantification of leaf-associated fungal species - A proof-of-concept using Alatospora pulchella. PLoS One 2017, 12 (4), No. e0174634.

(182) Wurzbacher, C.; Grimmett, I. J.; Bärlocher, F. Metabarcodingbased fungal diversity on coarse and fine particulate organic matter in a first-order stream in Nova Scotia, Canada. F1000Research 2015, 4, 1378.

(183) Fleeger, J. W.; Carman, K. R.; Nisbet, R. M. Indirect effects of contaminants in aquatic ecosystems. Sci. Total Environ. 2003, 317, 207-233.

(184) Rohr, J. R.; Kerby, J. L.; Sih, A. Community ecology as a framework for predicting contaminant effects. Trends Ecol. Evol. 2006, 21 (11), 606-613.

(185) Clements, W. H.; Rohr, J. R. Community responses to contaminants: using basic ecological principles to predict ecotoxicological effects. Environ. Toxicol. Chem. 2009, 28 (9), 1789-1800.

(186) Monsinjon, T.; Knigge, T. Proteomic applications in ecotoxicology. Proteomics 2007, 7 (16), 2997-3009.

(187) Viant, M. R. Applications of metabolomics to the environmental sciences. Metabolomics 2009, 5 (1), 1-2.

(188) Caquet, T. Use of carbon and nitrogen stable isotope ratios to assess the effects of environmental contaminants on aquatic food webs. Environ. Pollut. 2006, 141 (1), 54-59.

(189) Wieczorek, M. V.; Kötter, D.; Gergs, R.; Schulz, R. Using stable isotope analysis in stream mesocosms to study potential effects of environmental chemicals on aquatic-terrestrial subsidies. Environ. Sci. Pollut. Res. 2015, 22 (17), 12892-12901.

(190) Ek, C.; Karlson, A. M.; Hansson, S.; Garbaras, A.; Gorokhova, E. Stable isotope composition in Daphnia is modulated by growth, temperature, and toxic exposure: implications for trophic magnification factor assessment. Environ. Sci. Technol. 2015, 49 (11), 69346942.

(191) Kagami, M.; de Bruin, A.; Ibelings, B. W.; Van Donk, E. Parasitic chytrids: their effects on phytoplankton communities and food-web dynamics. Hydrobiologia 2007, 578 (1), 113-129.

(192) Gorokhova, E.; Rivetti, C.; Furuhagen, S.; Edlund, A.; Ek, K.; Breitholtz, M. Bacteria-mediated effects of antibiotics on Daphnia nutrition. Environ. Sci. Technol. 2015, 49 (9), 5779-5787.

(193) Wilson, E. R.; Smalling, K. L.; Reilly, T. J.; Gray, E.; Bond, L.; Steele, L.; Kandel, P.; Chamberlin, A.; Gause, J.; Reynolds, N.; Robertson, I.; Novak, S.; Feris, K.; White, M. M. Assessing the potential effects of fungicides on nontarget gut fungi (Trichomycetes) and their associated larval black fly hosts. J. Am. Water Resour. Assoc. 2014, 50 (2), 420-433.

(194) Schäfer, R. B. In response: why we need landscape ecotoxicology and how it could be advanced-an academic perspective. Environ. Toxicol. Chem. 2014, 33 (6), 1193-1194.

(195) Clements, W. H.; Hickey, C. W.; Kidd, K. A. How do aquatic communities respond to contaminants? It depends on the ecological context. Environ. Toxicol. Chem. 2012, 31 (9), 1932-1940. 
(196) Seeland, A.; Albrand, J.; Oehlmann, J.; Muller, R. Life stagespecific effects of the fungicide Pyrimethanil and temperature on the snail Physella acuta (Draparnaud, 1805) disclose the pitfalls for the aquatic risk assessment under global climate change. Environ. Pollut. 2013, 174, 1-9.

(197) Zubrod, J. P.; Bundschuh, M.; Schulz, R. Effects of subchronic fungicide exposure on the energy processing of Gammarus fossarum (Crustacea; Amphipoda). Ecotoxicol. Environ. Saf. 2010, 73, 16741680.

(198) Gonzalez-Ortegon, E.; Gimenez, L.; Blasco, J.; Le Vay, L. Effects of food limitation and pharmaceutical compounds on the larval development and morphology of Palaemon serratus. Sci. Total Environ. 2015, 503, 171-178.

(199) Fernández, D.; Voss, K.; Bundschuh, M.; Zubrod, J. P.; Schäfer, R. B. Effects of fungicides on decomposer communities and litter decomposition in vineyard streams. Sci. Total Environ. 2015, 533, 40-48.

(200) Rossaro, B.; Cortesi, P. The effects of tricyclazole treatment on aquatic macroinvertebrates in the field and in laboratory. $J$. Entomol. Acarol. Res. 2013, 45 (3), 23.

(201) Feckler, A.; Goedkoop, W.; Konschak, M.; Bundschuh, R.; Kenngott, K. G. J.; Schulz, R.; Zubrod, J. P.; Bundschuh, M. History matters: Heterotrophic microbial community structure and function adapt to multiple stressors. Glob. Chang. Biol. 2018, 24, e402-e415. (202) Tlili, A.; Berard, A.; Blanck, H.; Bouchez, A.; Cássio, F.; Eriksson, K. M.; Morin, S.; Montuelle, B.; Navarro, E.; Pascoal, C. Pollution-induced community tolerance (PICT): towards an ecologically relevant risk assessment of chemicals in aquatic systems. Freshwater Biol. 2016, 61 (12), 2141-2151.

(203) Hartung, T.; Rovida, C. Chemical regulators have overreached. Nature 2009, 460 (7259), 1080.

(204) Rohr, J. R.; Salice, C. J.; Nisbet, R. M. Chemical safety must extend to ecosystems. Science 2017, 356 (6341), 917-917.

(205) Rohr, J. R.; Salice, C. J.; Nisbet, R. M. The pros and cons of ecological risk assessment based on data from different levels of biological organization. Crit. Rev. Toxicol. 2016, 46 (9), 756-784.

(206) Nyman, A. M.; Schirmer, K.; Ashauer, R. Toxicokinetictoxicodynamic modelling of survival of Gammarus pulex in multiple pulse exposures to propiconazole: model assumptions, calibration data requirements and predictive power. Ecotoxicology 2012, 21 (7), $1828-1840$.

(207) Speck-Planche, A.; Kleandrova, V. V.; Luan, F.; Cordeiro, M. N. D. Predicting multiple ecotoxicological profiles in agrochemical fungicides: a multi-species chemoinformatic approach. Ecotoxicol. Environ. Saf. 2012, 80, 308-313. 